\title{
Psychopathy and motivational internalism
}

\author{
Reza Mosmer ${ }^{1 *}$ \\ 1. Assistant Professor of Philosophy, Department of Philosophy of Mind, Institute for Cognitive Science Studies (ICSS), Tehran, Iran
}

Recieved: 31 May 2018

Revised: 20 Dec. 2018

Accepted: 31 Dec. 2018

Keywords

Motivational internalism

Motivational externalism

Psychopathy

Morality

Blair

Sinnott-Armstrong

\section{Corresponding author}

Reza Mosmer, Assistant Professor of Philosophy, Department of Philosophy of Mind, Institute for Cognitive Science Studies (ICSS), Tehran, Iran

Email: Rezamosmer@yahoo.com

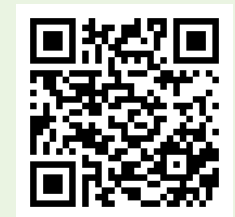

doi.org/10.30699/icss.21.3.130

\section{Abstract}

Motivation in general and moral motivation, in particular, has been highly-discussed subject among psychologists and philosophers. The question of what mental states necessarily lead to moral behaviors has received various answers. Motivational internalists about moral judgement have argued that moral judgements necessitate moral behaviors. Among them, sensationalists take moral judgements to be expressions of emotions, whereas internalists about moral beliefs entertain the thought that moral judgements are expressions of moral beliefs. On the contrary, motivational externalists about moral beliefs speak of the conceivability of an individual who has a moral belief but due to a lack of desire to act morally, individual is not motivated to act upon her/his belief (the case of amoralist). Furthermore, motivational internalists hold that amoralism is more than a mere intellectual possibility; they take the case of "psychopathy" as a realization of this abstract possibility. They claim that empirical findings of Blair's studies on psychopath prisoners provide counter-evidence to the externalist thought that psychopaths are threats to internalism. Among advocates of motivational internalism, Sinnott-Armstrong has used Blair's empirical findings along with a philosophical argument (argument from an analogy between morality and art) to establish that psychopathy is not a threat to internalism. The present study is an attempt to reveal that (a) Sinnott- Armstrong's argument is not effective, and (b) motivational internalism relies on a false premise.

Citation: Mosmer R. Psychopathy and motivational internalism. Advances in Cognitive Sciences. 2019;21(3):130-144. 


\section{روانبيمارى و درونكرايى انكيزشى}

(iD)" رضا مثمر

ا. استاديار فلسفه، كروه فلسفه ذهن، موسسؤ آموزش عالى علوم شناختى، تهران، ايران

\section{ars}

انگيزش به طور كلى و انگيزش اخلاقى به طور خاص موضوع بحث روانشناسان و فيلسوفان بوده است. برسش از اين كه جه حالت يا حالتهاى ذهنياى ضرورتاً منجر به بروز رفتارهاى اخلاقى مىشود ياسخهايى متفاوت دريافت كرده است. درون كرايان انكيزشى درباره احكام اخلاقى از آن كفتهاند كه احكام اخلاقى ضرورتاً موجب بروز رفتارهاى اخلاقى مىشوند. برخى از اين فيلسوفان اظهار كردهاند كه احكام اخلاقى نموداركنندة عواطف و احساس هاى آدمى هستند (احساسات گرايان اخلاقى) و برخى ديكر به آن راه رفتهاند كه احكام اخلاقى بيان كنندة باورهاى اخلاقى آدمى هستند

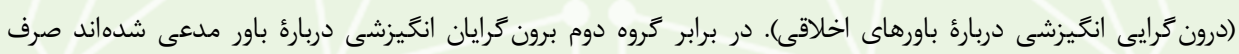
حالت ذهنى باور براى انگيزه كفايت نخواهد كرد و نياز به وجود حالت ذهنى ميل نيز خواهد بود. به نظر ايشان مى توان موجوداتى را تصور كرد كه به زعم داشتن باورهاى اخلاقى انخيزهاى براى كنش اخلاقى نداشته باشند (افراد ناخلاقى). افراد ناخلاقى فاقد ميل به عمل اخلاقى هستند. افزون بر اين به نظر ايشان موارد روانبيمارى نمونههايى واقعى از مورد فرد ناخلاقى هستند. در برابر ايشان درون گرايان استدلال كردهاند كه روانبيماران تهديدى براى درون كرايى انگَيزشى دربارٔ باورهاى اخلاقى نيستند. ايشان از تحقيقات تجربى بلر (Blair) بر بزهكاران روانبيمار براى يشتيبانى از اين ادعاى خويش بهره كرفتهاند. در اين مقاله مى كوشم با بررسى استدلالى كه سينوت-آرمسترانگ (Sinnott-Armstrong) با تكيه بر يافته هاى بلر براى ادعاى فوق مى آورد نشان دهم كه تلاش وى كوششى ناكام است. در انتها نيز استدلال خواهم كرد فاغ از كاميابى يا ناكامى استدلال سينوت-آرمسترانگ، درون كرايى بر فرضى از اساس كاذب مبتنى است.

دريافت: • • اصلاح نهايى:

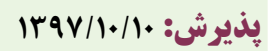
وازههاى كليدى درون گرايى انخيزشى برون كرايى انخيزشى

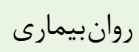
اخلاق بلر سينوت-آرمسترانگ سلاق بلر نويسناه مسئول رضا مثمر، استاديار فلسفه، تروه فلسفه ذهن، موسسؤ آموزش عالى علوم شناختى، تهران، رهنا

ايميل: Rezamosmer@yahoo.com

\section{口候品

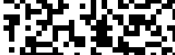 arping}

doil doi.org/10.30699/icss.21.3.130

dolä

مى انخيزد يا خير، سؤالى است كه فيلسوفانى پاسخش را مثبت دانستهاند و فيلسوفانى هم منفى. گَروه نخست به درون گر ايى انخيزشى درباره باورهاى اخلاقى (Motivational Internalism about Moral Beliefs) معتقد هستند (1) و گروه دوم به برون گرايى انخيزشى درباره باورهاى اخلاقى (Y) (Motivational Externalism about Moral Beliefs)
انخيزش و به ويزه انخيزش اخلاقى موضوع بحثهاى دراز دامنى در ميان

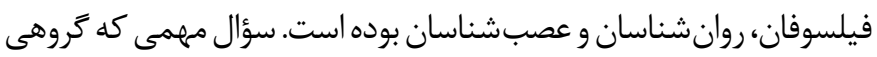
از فيلسوفان اخلاق را به خود مشغول داشته است يرسش از رابطهُ ميان باورهاى اخلاقى و كنشهاى آدمى است. اين كه آيا داشتن باور اخلاقى

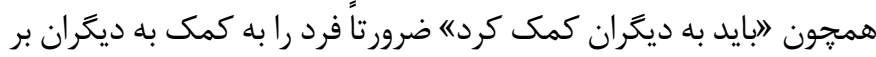


است \امروز ظهر برف سهمناكى خواهد باريد و جز با تجهيزات اسكى

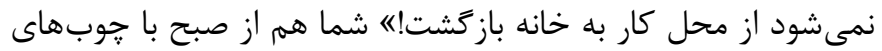

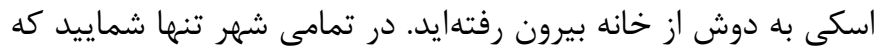

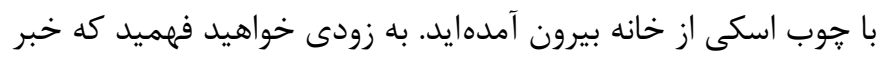
كذب محض بوده است! مى توان يرسيد:

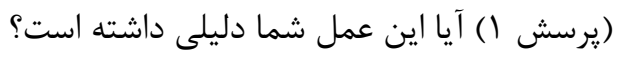

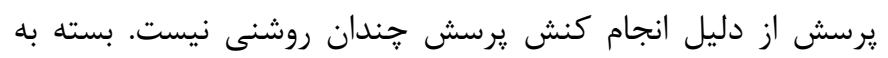

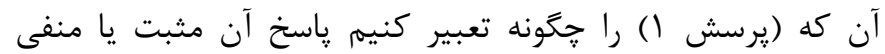
خواهد بود. يك بار سؤال از دليل شما براى همراه بردن تجهيزات اسكى معطوف به همأ آن جيزهايى است كه هنغام تصميم كيرى براى بردن وسايل اسكى شما را به اين كار برانگيخته است. به سخنى ديخر (يرسش () را مىتوان يرسش از جند و جون وضع ذهنى و حالتهاى إنى ذهنى شما يِش از انجام عمل دانست. اين حالتهاى ذهنى از راه

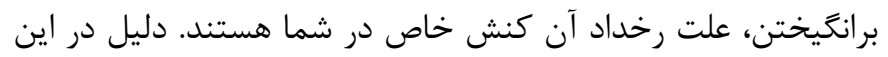

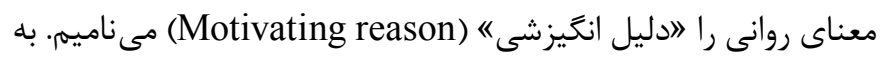
اين ترتيب راه نخست تعبير (يرسش () اين است:

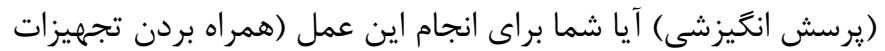

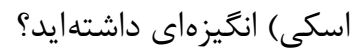
راه دوم خواندن (يرسش () اين است كه بيرسيم آيا كار شما يعنى به همراه بردن تجهيزات اسكى در روزى كه قرار نيست هركز دانهٔ برفى از آسمان بر زمين بيفتد موجه بوده است يا نه؟ به عبارت ديكر آيا رفتار

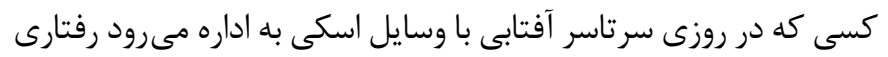

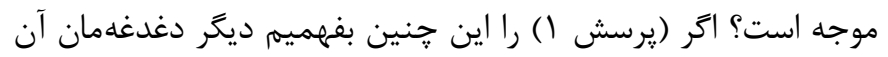

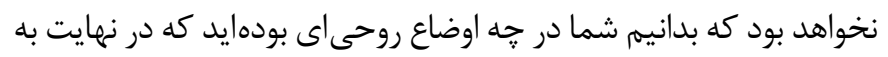

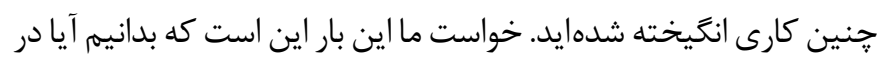

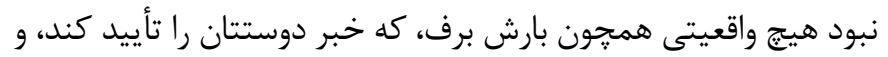
از قضا در حضور واقعيتى مانند نباريدن برف، كه خبر دوستتان را تكذيب مى كند، كار شما مىتواند هيج دليل و توجيهى داشته باشد؟ دليل در اين معناى واقعيتبار (Factual) را 》دليل هنجارى" (Normative)

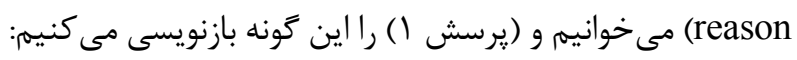

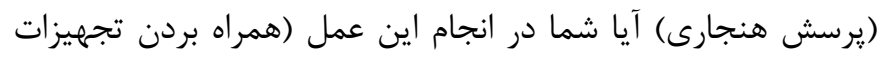

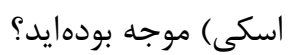

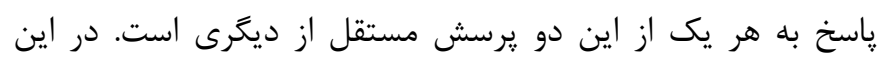

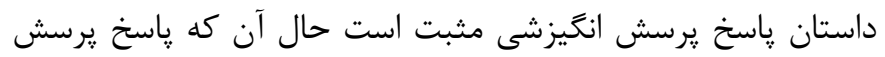

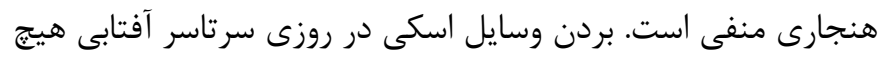
توجيهى ندارد اما اكر شما به خاطر باورى كاذب همجيون باور به اين كه

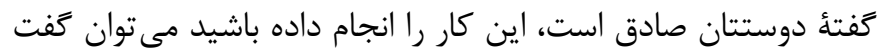

يس از دو اصطلاح "درون گرايى" و "برون گرايى" به عنوان اختصارهايى براى اين دو رويكرد استفاده خواهم كرد. برون ناخلاقى (The Amoral) يا افرادى صحبت كردهاند كه داراى باورهاى

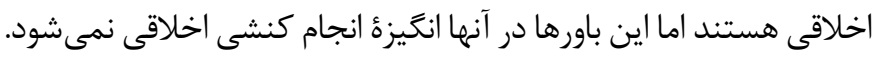

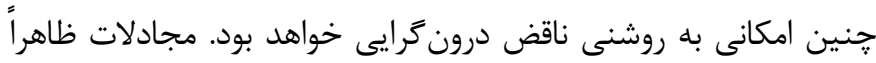
بى يايان اين دو گروه كسانى را بدان سوى سوق داده است كه به به دنبال

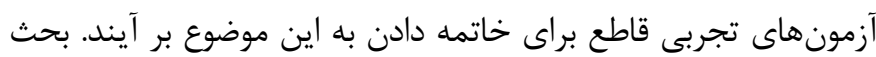

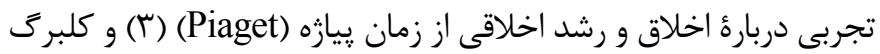

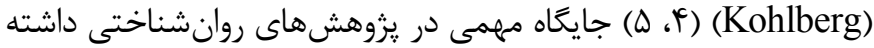
است. با اين همه تحقيقات اخير توريل (Turiel) و همكارانش (4-A) از واقعيتهاى تازهاى دربارة روان انسان يرده گرفته است كه شايد مهمترين آنها اين نكته است كه انسانها از دوران كودكى توانايى بازشناسى تخلف از ازئان

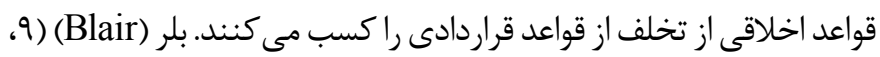
• (1) با كاربست آزمونهاى توريل بر بزهكاران روانبيمار (Psychopath)

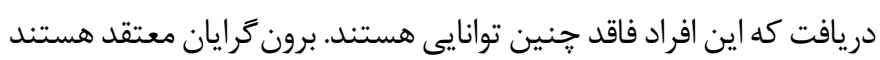
كه روانبيماران نمونههاى واقعى و تحقق يافتهٔ موجودات ناخلاقى هستند. بر خلاف، درونَرايان معتقد هستند كه روانبيماران تهديدى براى درون كرايى نيستند جرا كه فاقد باورهاى اخلاقى هستند. ايشان يافتههاى درى بلر را كواهى براى تصديق درون كرايى ميبينند. در اين مقاله پِ إز شرح

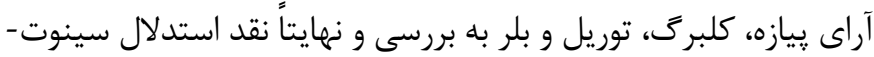

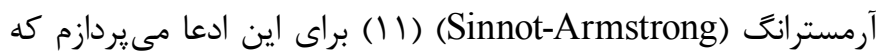
روانبيماران فاقد باورهاى اخلاقى هستند.

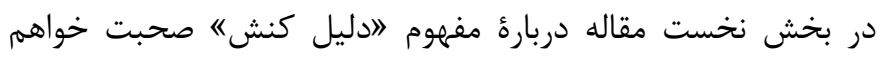

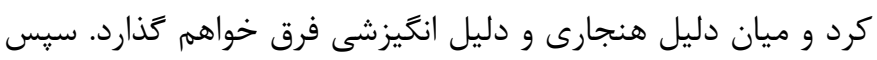

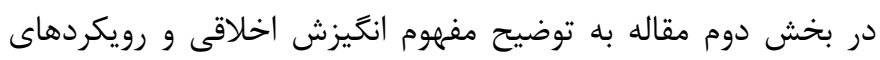

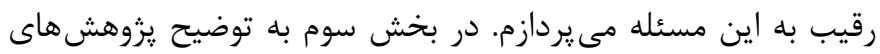

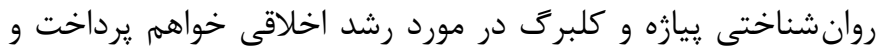
آزمايش توريل و همكارانش را توضيح خواهم داد. در بخش جهارم

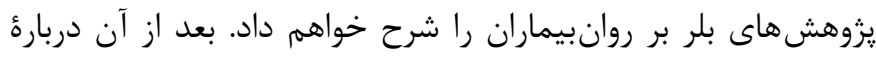
ييشفرضها و دلالتهاى فلسفى اين يزوهش ها صحبت كنم و سيس ريس

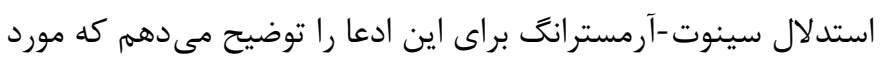

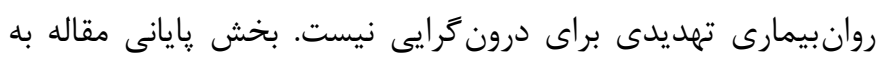

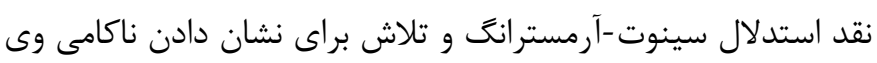

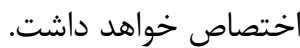

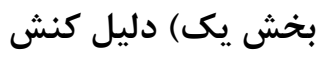
دوستى كه در هواشناسى كار مى كند به شما زنخ زده است و كفته 
درباره لاحكم/هاى اخلاقى است و نه "اباور"هاى اخلاقى. باورها جزء اثاثيئ ذهن هستند و باور كردن وضعيتى است كه ذهن ممكن است در لحظهاى در آن به سر ببرد. بر خلاف باور كردن، حكم كردن رفتارى زبانى است و حكم آن هيزى است كه در اين رفتار زبانى بروز مى يابند. به عبارتى ديخر حكمها همان جمله هاى به كار رفته در زبان هستند. با اين اوصاف منظور از حكم اخلاقى جيزى نيست مگر جملة اخلاقى

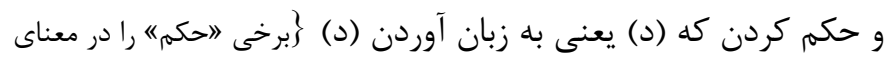

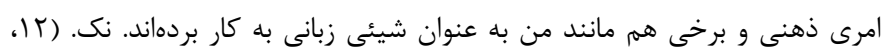

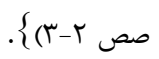

آموزه دوم شناخت گرايى اخلاقى آموزهاى معناشناختى است به اين معنا كه درباره هويت بخشى از زبان يعنى زبان اخلاقى و احكام يا جملههاى آن سخن مى گويد. مطابق اين آموزه جملههاى اخلاقى نمودار كننده باورهاى اخلاقى ما هستند. باور اخلاقى رويكردى شناختى است. همانطور كه باور شما به آن كه جنگل (Cognitive attitude) آمازون در امريكاى جنوبى است بخشى از شناخت جغرافيايى شما را از جهان مى سازد، باورتان به (د) هم بخشى از شناخت اخلاقى شما را سامان مى دهد. از تركيب درون گرايى انگیزشى درباره احكام اخلاقى و شناخت گرايى اخلاقى مى توان درون گرايى را نتيجه گرفت راصطلاح Expression ترجمه كردهام. دليل اين كار هم آن است كه وازههاى اظهار، ابراز و بيان داراى بار زبانى هستند حال آن كه تغييرات جهره يا حركات بدنى هم مى توانند بازنمايندة جيزى باشند بى آنكه جيزى به زبان آمده باشد. از قصد به جاى "ابيانه از "نمودار"

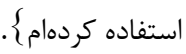
در برابر مدافعان درون گرايى انخيزشى دربارهٔ باورهاى اخلاقى، فيلسوفانى يا با رد درون گرايى انگيزشى دربارؤ احكام اخلاقى يا با انكار شناخت گرايى اخلاقى براى (يرسش r) پاسخى منفى تداركى كردهاند و

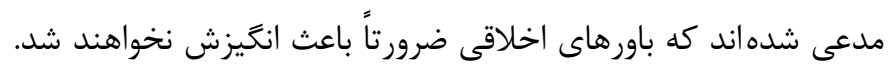
كسانى را كه از راه انكار شناخت گرايى اخلاقى آمدهاند احساسات گرايان اخلاقى (Moral Sentimentalism) مى خوانند. احساسات گرايان اناشناخت گرايى اخلاقى" را به جاى شناخت گرايى اخلاقى مىنشانند:

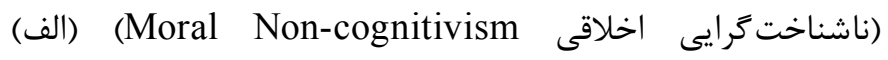
حكم هاى اخلاقى نمودارهاى باورهاى اخلاقى نيستند و (ب) حكمهاى اخلاقى نمودارهاى عواطف و احساسات آدمى هستند إخنان كه در تعريف ناشناخت

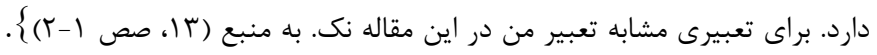

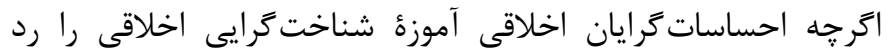
مى كنند، همجنان مدافع آموزه درون گرايى انگيزشى درباره احكام
باور كاذبتان شما را به اين كنش برانخيخته است جتوضيحى مستوفا دربارءٔ

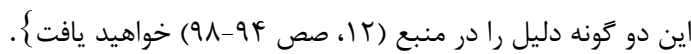

\section{بخش دو) انخيزش اخلاقى}

دربارهٔ ربط ميان حالت ذهنى باور در شما و انگيزهان به انجام كارى خاص حرف زدم. بحذاريد كامى ديخر بردارم و از آن بيرسم كه آيا باورهاى اخلاقى ما هم داراى توان انخيزشى هستند و مى توانند ما را إنى به انجام كارى اخلاقى برانگيزند؟ به سخنى ديخر آيا اخر باورى داشته باشيمم مانند اين: (د) باور به اين كه دستخيرى از ديخران خوب است.

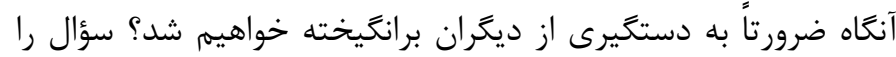

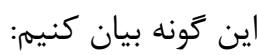
(يرسش r) آيا ميان باورهاى اخلاقى ما و انخيزههايمان رابط هاى ضرورى ليبان

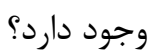
فيلسوفانى به اين گرسش مثبت ياسخ دادهاند و گفتتاند كه ميان داشتن

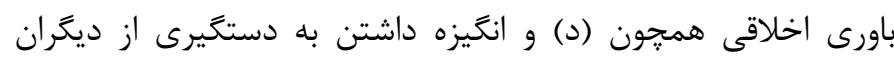
رابطهاى مفهومى و درونى وجود دارد. به باور ايشان تنها و تنها زمانى به دستخيرى از ديخران برانگيخته خواهيم شد كه به (د) باور داشته باشيم جرا كه جنين باورى براى آن انگيزش ضرورى است. اين رويكرد را كه "درون گرايى انخيزشى درباره باورهاى اخلاقى" يا به اختصار "درون گرايى" مى نامم مى توان اين گونه صورتبندى كرد: (درون گرايى انخيزشى درباره باورهاى اخلاقى) ضروت دارد كه اخر فردى مدى باور داشته باشد كه (د)، آنگاه وى برانخيخته مى شود كه طبق (د) عمل كند \{اين تعريف درون كرايى در ساده ترين شكل آن است. نوع پِيجيدهتر آن واجد

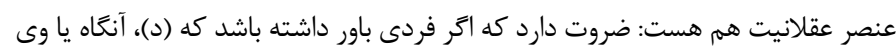
برانكَيخته خواهد شد كه طبق (د) عمل كند و يا آن كه فاقد عقلانيت عملى است. براى توضيح مفصلتر اين تعريف بنكريد به (1، ص •و به بعد). نظر به آن كه در اين مقاله عنصر عقلانيت عملى مهم نيست من به تعريف سادؤ درون گرايى بسنده خواهم كرد مطابق اين رويكرد هيج جهان ممكنى نيست كه در آن شما باور داشته باشيد كه (د) اما انخيزهاى براى عمل بر طبق (د) نداشته باشيد. درون گرايى از دو آموزه شكل گرفته است: درون گرايى انخيزشى دربارة احكام اخلاقى (Motivational Internalism ضروت دارد كه اگر فردى حكم كند كه (about Moral Judgments (د) آنغاه او برانگيخته خواهد شد كه طبق (د) عمل كند. شناخت گرايى اخلاقى (Moral Cognitivism) حكمهاى اخلاقى نموداركنندهاى باورهاى اخلاقى هستند. روشن است كه آموزه نخست درون گرايى انخيزشى دربارهٔ احكام اخلاقى 
به اين كه جنكل كلستان در حال نابودى نباشد هيج بخشى از دانش

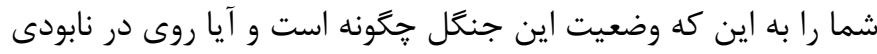
دارد يا خير، شكل نمى دهد. آنجه در شناخت شما به جهان مهرم است مجموعة باورهاى شما است نه مجموعة اميالتان.

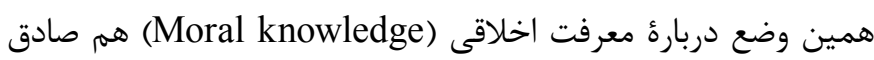

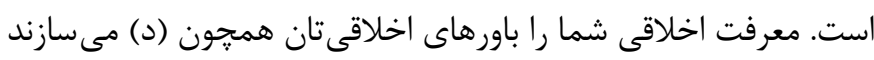
و نه ميلى همجون ميل زير: (م) ميل به اين كه كار خوب را انجام داد. به زعم برون رايان، انخيزش اخلاقى زمانى روى مىدهد كه به باور

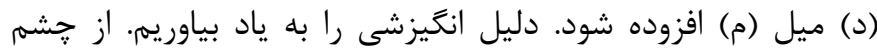

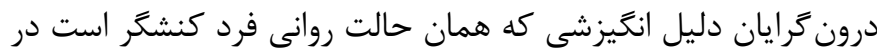

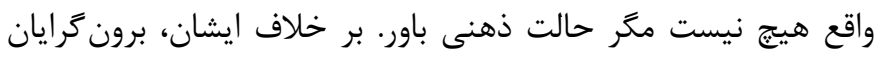

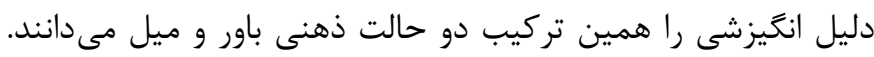

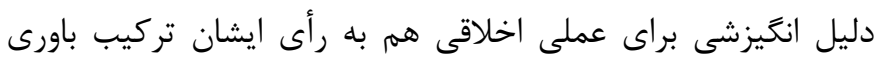

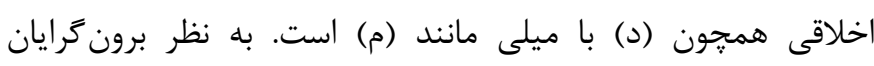

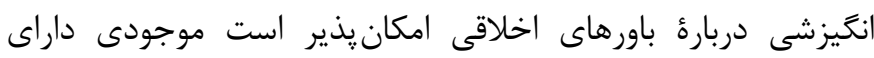

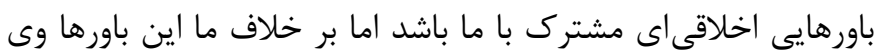

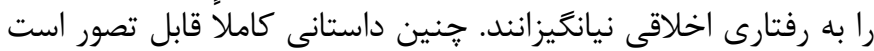

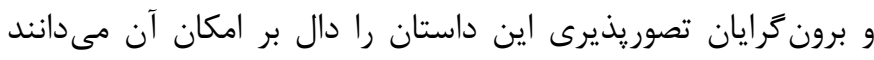
\}رابطه امكان و تصوريذيرى محل مناقشئ فيلسوفان بوده است. براى نمونه بنكريد

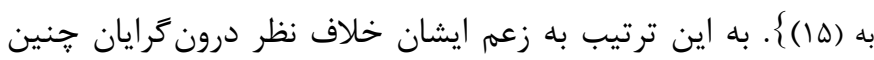

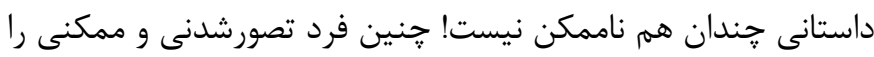
"انسان ناخلاقى" يا "بى اعتنا به اخلاق" (Morally Indifferent)

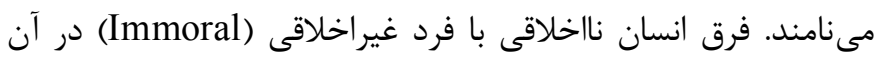
است كه فرد غيراخلاقى باورهايى متفاوت با باورهاى ما دارد و مثلاً به فيه

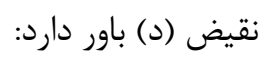

(ن د) باور به اين كه هنين نيست كه دستخيرى از ديخران خوب است. فرد ناخلاقى اكر جه مانند انسان غير اخلاقى به ديخران كمك نمى كند،

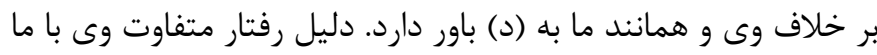
آن است كه او بر خلاف ما فاقد ميلى همرجون (م) است. به قول برينك

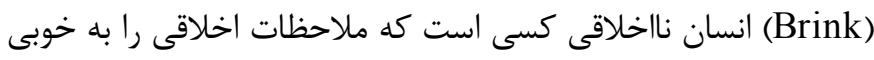

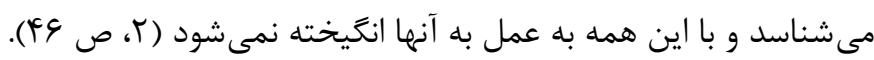

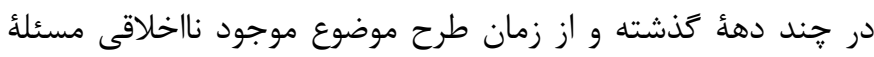

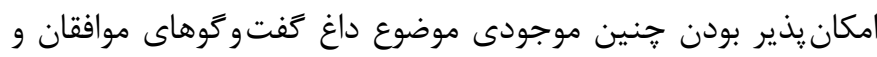
مخالفان درون كرايى انخيزشى دربارة احكام اخلاقى بوده است. يكى از

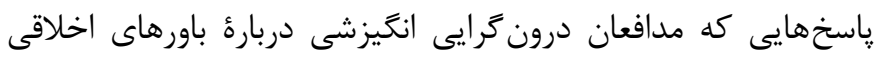

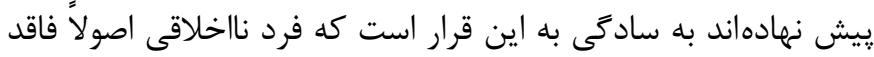

اخلاقى هستند. انكار شناخت گرايى اخلاقى براى احساسات گرايان اخلاقى بسيار حساس و اساسى است جرا كه با انكار اين آموزه ديكر

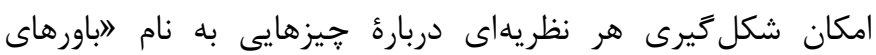

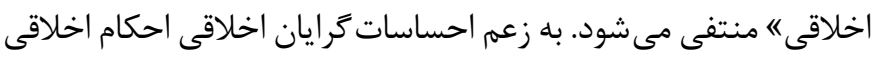

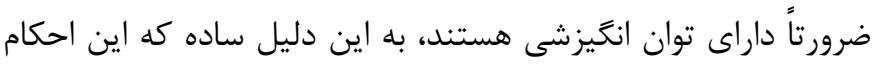
نموداركننده عواطف آدمى هستند و عواطف و احساس هاى انسان ذان ذاتاً

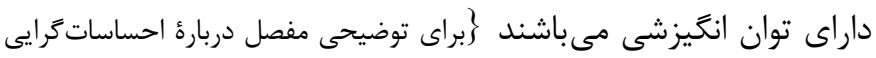

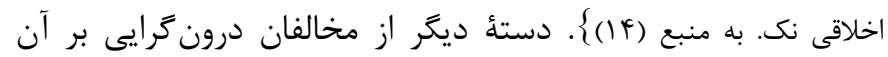
هستند كه رابطؤ ميان احكام اخلاقى و انغيزش به عمل به آنها،

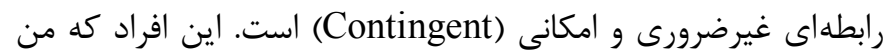

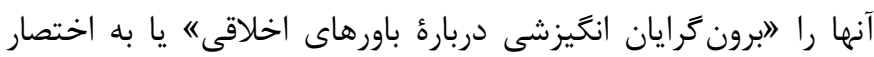
"برون گر ايان" مي خوانم، معتقد به اين آموزهاند:

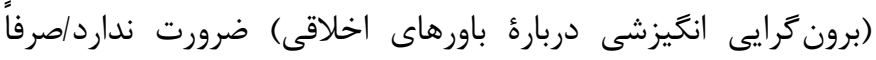

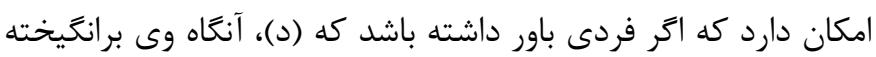
شود كه طبق (د) عمل كند.

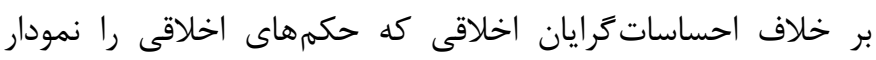
باورهاى اخلاقى نمى دانند برون كرايان همجون مدافعان درون كرايى بها شناخت گرايى اخلاقى اعتقاد دارند. با اين حال بر خلاف درون كرايان

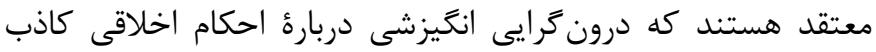
است و احكام اخلاقى ذاتاً و به تنهايى نمى توانند فرد را به به انجام اعمال

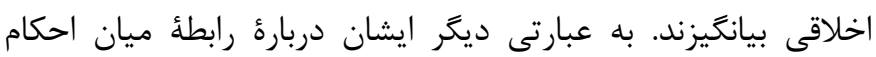
اخلاقى و انخَيزش اخلاقى برون about Moral Judgements (برون گرايى انكيزشى درباره احكام اخلاقى) ضرورت ندارداصرفاً امكان

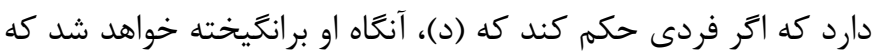

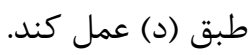
بنا بر نظر برون كرايان انكيزشى درباره احكام اخلاقى حكم (د) ضرورتاً

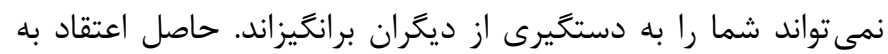

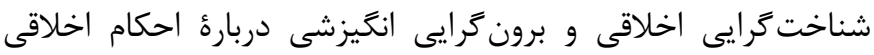

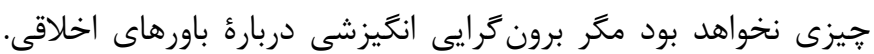

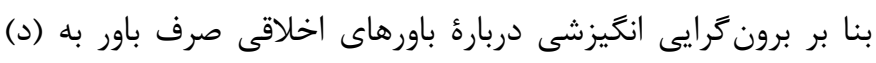

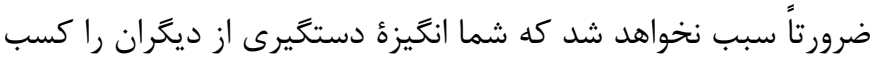

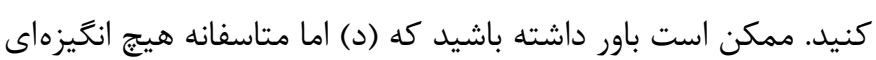

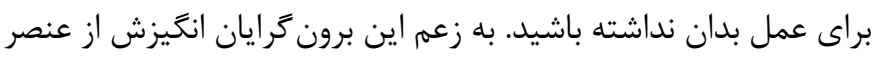

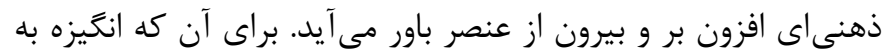

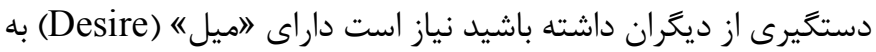
اين كار باشيد. "ميل" رويكردى ذهنى اما غيرشناختى است. ميل شما دان 
شخصيتى تخيلى و داستانى، بلكه موجودى واقعى است و مىتوان در جهان زندگى روزمره مصداقهاى آن را نشان داد. به نظر ايشان افراد روانبيمار نمونههايى حقيقى از موجود ناخلاقى هستند. اگر جنين

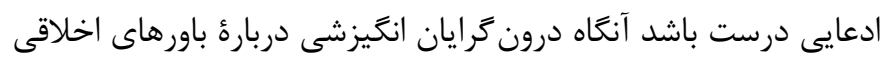

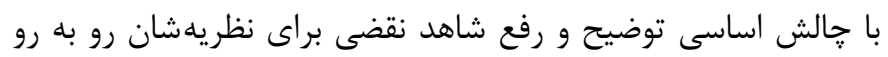

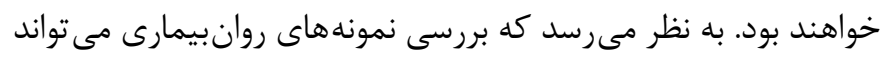

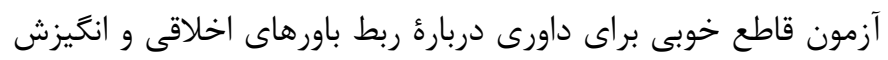

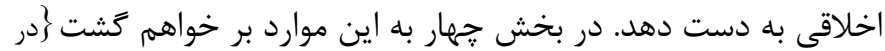

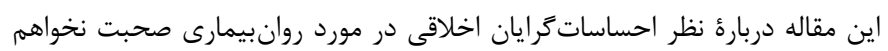

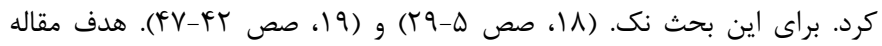
بررسى اهميت و توان روان بيمارى در فيصله دادن مناقشئ برون كرايى با نوع خاصى از درون كرايى يعنى نوعى كه متعهيد به شناخت كرايى است مى باشد

\section{بخش سه) مطالعات روانشناختى بر رشد اخلاقى: از ييازه تا توريل}

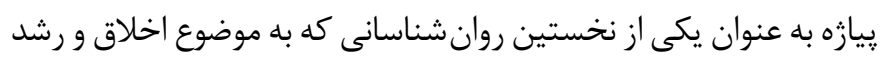
اخلاقى در كودكان يرداخته است، رشد اخلاقى را فرايندى مىشمارد كه در آن ساختارهاى شناختى حاكم بر رفتار و انديشههاى كودى طى مراحلى و در نتيجهٔ توسعة تعاملهاى اجتماعى او تغيير مى يابد و در نتيجه كودى از مرحلة ااخلاق دخرييروى" Heteronomous) (Mutonomous Morality) به مر حلئ 》اخلاق خودمختار (Morality

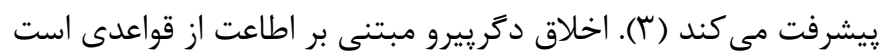

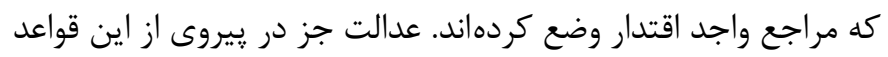
فهميده نمى شود و پيامدهاى كنش مهمتر و حياتى تر از مقاصد ينهان

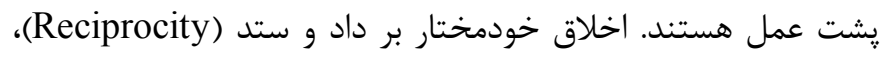

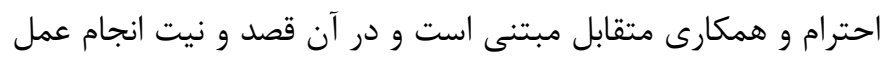
اهميتى اساسى دارد. به عبارت ديخر رشد اخلاقى كودى عبارت است از فرايندى كه در آن درك كودى از مفهوم "اعدالته تغيير مى كند، قواعد اخلاقى آهسته آهسته از قواعد قراردادى (Conventional) جدا مىشوند و كودى قادر به تشخيص و جدا كردن اين دو دسته قاعده از يكديگر مىشود. به نظر مىرسد كودكان از دو و نيم سالكى قدرت تشخيص دادن اين قواعد را كسب مى كنند.

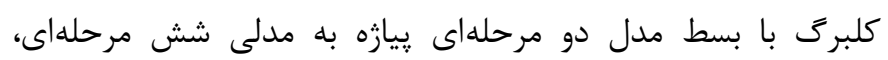

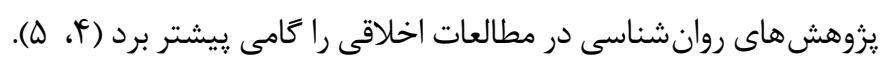
با اين همه تحقيقات كلبرى در ييشفرضى با كارهاى ييازه اشتراك داشت: (ييشفرض) "ارشد اخلاقى متضمن تمايز تدريجى اخلاق (انصاف) از

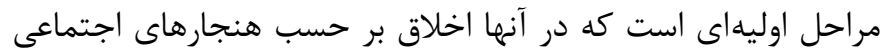

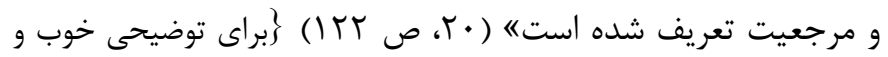

باورهاى اخلاقى است و تنها دليل آن كه وى انخيزهاى براى عمل اخلاقى ندارد هم همين است. درون گرايان از دو راه با داستان لاموجود

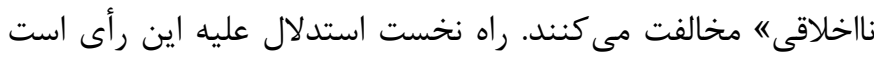

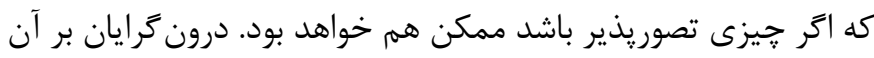

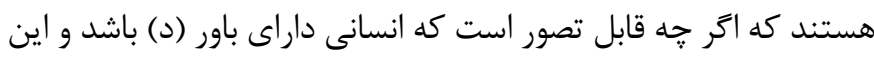

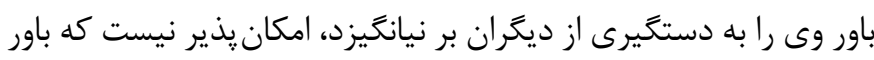

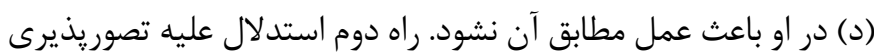

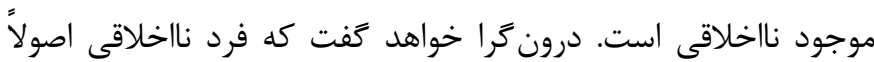

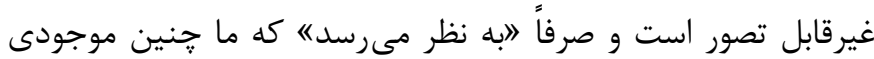
را تصور كردهايم. آنجه در واقع امر تصور كردهايم انسانى است كه فاقد

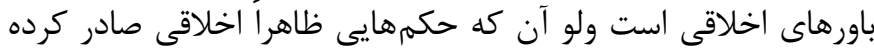

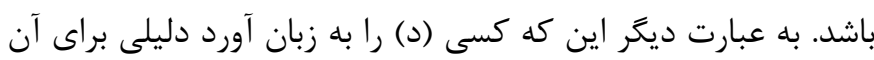

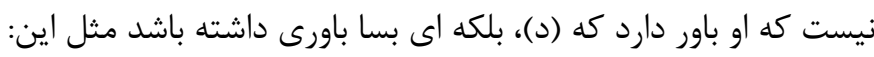

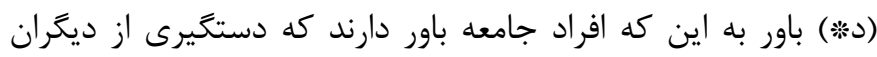

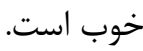
بر خلاف (د) كه باورى هنجارى و اخلاقى است، (د*) باورى است توصيفى و دربارهٔ باورهاى جامعهاى كه فرد حكم كننده در آن زندكى بأى مى كند. روشن است كه نمىتوان از (دق) انتظار داشت كويندهاش را دار به انجام عملى مطابق با (د) بيانكَيزاند. در خنين وضعى غريب هم ادمان

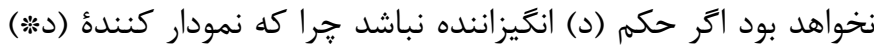
است. به اين ترتيب فرد ناخلاقى يِيش از آن كه امكان يذير باشد حتى إنى

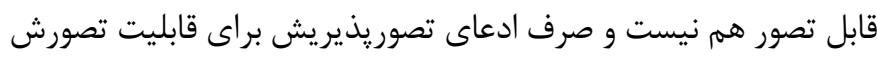
كافى نيست. آنجه در واقع امر تصور شده است فردى است با باور (د**)، و نه باور اخلاقى (د). مناقشٔ ميان درون كرايان و برون گرايان بيش از سه دهه قدمت دارد و به رغم استدلالها و تدقيقهاى جندين و جندباره هر دو خروه مىنمايد كه هنوز همان جايى هستيم كه سى سال ييش بودهايم. برينز (Prinz) (ع)، ص هD) علت اين امر را راهبرد ناموثرى مىداند كه هر دو سوى مناقشه يى گرفتهاند: راهبرد ارجاع به شهود أنيز نك.

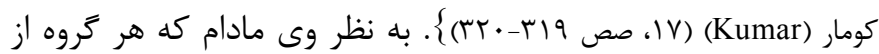
شهودهاى خود براى اثبات حرف خويش بهره بجويد كامى از ييش

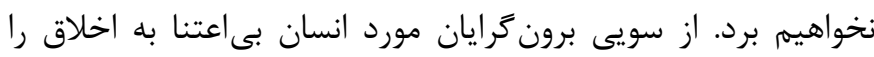

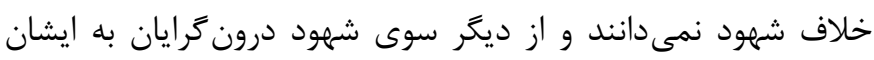

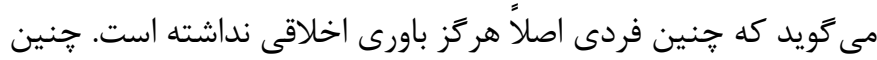
بنبستى فيلسوفانى را به جستجوى راهحلى تجربى، قاطع و فارغ از شهودهاى متعارض دو سوى مناقشه سوق داده است. برون كرايان انكيزشى درباره باورهاى اخلاقى ادعا كردهاند كه موجود ناخلاقى نه 
قواعد قراردادى نيز به كار برد و اين اصطلاحها قادر به متمايز كردن قواعد اخلاقى از قراردادى نيستند. نيكلز (Nichols) نيز با ارجاع به تحقيقات هايت (Haidt) و همكارانش از آن مى كويد كه اتخطىهاى مبتنى بر آسيب همهٔ امور در حوزءٔ اخلاق را توضيح نمىدهند. براى نمونه ما يرداخت نكردن ماليات را نادرست مىدانيم با اين كه اين كار به آسيب مستقيم جندانى منجر شود.《 (1)، صص V-9) و كاربست مفهوم 》آسيب" براى تمايز اخلاقى/قراردادى را ناموثر مىشمارد. با اين همه نيكلز معتقد است كه 》اكر خه تخلفهاى مبتنى بر آسيب نمىتوانند همأ امور در حوزه اخلاق را توضيح دهند مى توان داورى بر حسب تخطى منجر به آسيب را هستهٔ حكم اخلاقى

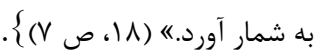
بر خلاف قواعد اخلاقى، تخطى از قراردادهاى اجتماعى كمتر جدى انگاشته مىشود و توجيه براى ممنوعيت اين دسته از تخلفها نقشى است كه اين قراردادها در سامان دادن به تعامل هاى اجتماعى و انتظام جامعه ايفا مى كنند. جنين قواعدى را مى توان تغيير داد و با تغيير آنها امرى را كه تا امروز خلاف محسوب مىشده است به يكباره مجاز كرد. آزمون هاى توريل و همكارانش عموماً اين سه كام را طى مى كنند:

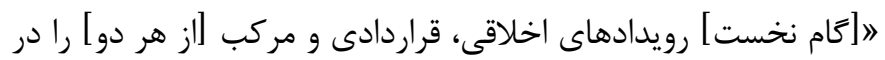
كلاس، زمان بازى يا استراحت كودكان در حياط مدرسه و موقع ناهار مشخص مى كنيه. [عام دوم] كمى يس از آن كه رويداد را مشاهده كرديم از برخى از شركت كنند كان در مطالعه مى خواهيم كه بخُويند جه تصويرى از موقعيت مشاهده شده دارند، رويداد را جَگونه ارزيابى مى كنند و داوريشان درباره رويداد جه است (همان "داوريهاى معيار" كه دربارهشان بحث شد) و [عام سوم] دلايلشان را براى داورى و و و

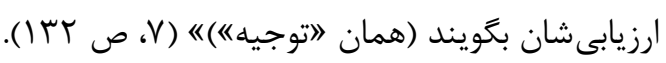
جنان كه نقل فوق از توريل دلالت مى كند وى دو مقوله را در تحقيق خود از يكديخر متمايز كرده است: معيار داورى، يا آنجه او لاداورى لهى

معيار" مى نامد، و "توجيه"، وى جنين مى گويد: ا|رزيابى داورىهاى معيار مشتمل است بر يرسش هايى از اين دست كه آيا فلان عمل در غياب قاعده و قانون درست است يا نادرست و اگر مرجع اقتدارى (مثلاً آموز كار در مدرسه) انجام عملى را مجاز بداند آيا آن كار درست خواهد بود و آيا توافق عمومى بر يذيرش عملى باعث درست بودن انجام آن كار خواهد بود و اين كه اخر كنشى را كروهى يا

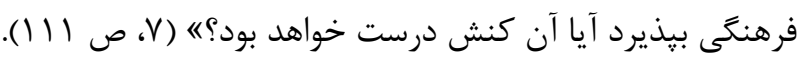
داورىهاى معيار به ما معيارهايى به دست مى دهند كه با آنها بتوانيم تخطى هاى اخلاقى را از تخطى هاى قراردادى متمايز كنيم. اين معيارها صورى هستند و صورى بودنشان قرار است لاحدود و صغور انتزاعى و كلىاى فراهم كند كه خصيصdهاى اساسى حكم اخلاقى را مشخص نمايد و حكمم اخلاقى را از ديخر انواع حكم (مثلاً حكم
مقدماتى دربارهٔ آراى كلبرگ بنَّريد به (I) ييازه و كلبرى هر دو، به رغم تفاوت نظرشان در مورد مراحل سنى رشد اخلاقى، معتقد بودند كه رشد اخلاقى در آدمى فرايند شكل گيرى قدرت تمايز نهادن ميان قواعد اخلاقى و قراردادهاى اجتماعى است. جنين يیشفرضى بى مخالفخوان نماند و سالها بعد توريل و نوجى (Nucci) از هنجارهاى اخلاقى و قراردادى (ييشفرض) را به جالش كشيدند. توريل

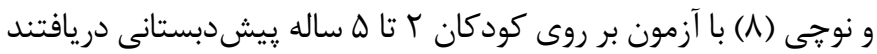
كه بر خلاف نظر كلبرگ و ييازه كودكان بين r تأ أ سالتى و در واقع در همان سنين اوليه به خوبى توانايى بازشناختن و جدا كردن قواعد اخلاقى از قواعد قراردادى را كسب مى كنند. به عبارت ديخر كودكان نيز همجون بزر گسالان قادر به جدا كردن تخطى از قواعد اخلاقى و تخطى از قواعد قراردادى هستند. معناى اين حرف آن است كه الرارداد اجتماعى بـى و اخلاقى دو دامنهٔ مفهومى مجزا از هم هستند كه تحليل رشد هر يك مستقل از تحليل رشد ديخرى است. به اين ترتيب اين رويكرد را كه رشد اخلاقى متضمن فرايند پيشروندهُ تميز دادن اخلاق از قرارداد است (نك.

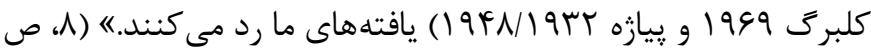

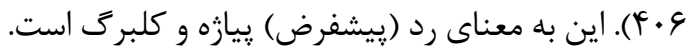
بحذاريد كمى درباره تمايز امر اخلاقى و امر قراردادى حرف بزنم. توريل سؤالهايى ييش مى نهد كه نوع پاسخ به آنها معيارهايى به دست مى دهد براى اين كه قاعدهاى قراردادى باشد يا اخلاقى. سؤالهاى توريل، يرسش هايى درباره تخطى از قاعده هستند:

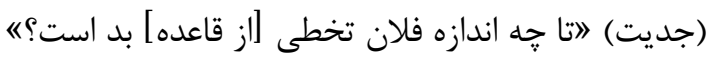
(توجيه) 》جرا فلان تخطى از قاعده بد است؟؟ ")

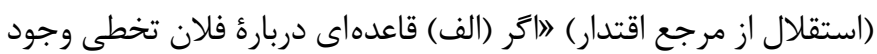
نداشت و يا (ب) مرجع قدرتى آن را مجاز مىشمرد آيا انجام آن كار درست مى بود؟) \}براى بحث دربارهٔ بستگى به مرجع قدرت و بستخى به قاعده

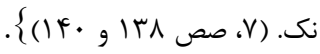
تخلف از قواعد اخلاقى جدىتر از تخلف از قراردادها است و توجيهى كه براى شنيع بودن تخطى از قاعدهاى اخلاقى ارائه مىشود عبارت از اين است كه تخطى از قواعد اخلاقى به ديخران آسيب بدنى يا روانى مى رساند، كارى نامنصفانه است و رفاه ايشان را در مخاطره مى اندازد. در نهايت آن كه حرمت اخلاقى يكى عمل، مستقل از رأى جامعه يا ₹روههاى صاحب قدرت يا قوانين اجتماعى است كسانى معيار "آسيب" و "بىعدالتى" را در كار توريل و نوجى مورد مناقشه قرار دادهاند و آنها را براى

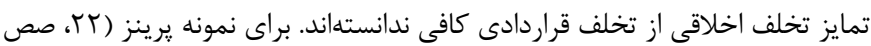

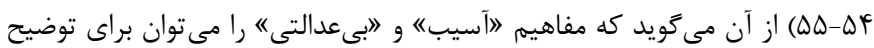


(استقلال از مرجع اقتدار) را كذارد. با اين حال اجازه دهيد اين كار را

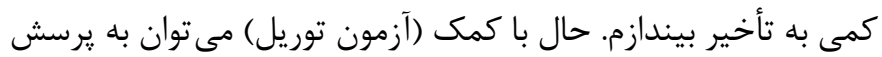

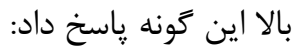
(توانايى بازشناسى) كسى داراى توانايى بازشناسى قواعد اخلاقى از باز

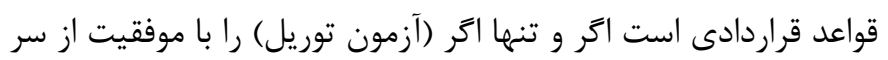

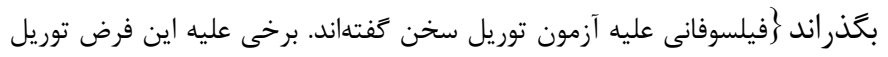

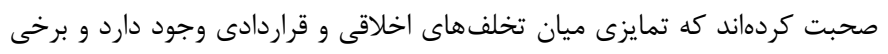
ديكر از آن كفتهاند كه ولو كه جنين فرضى هم صادق باشد ضرورتى ندارد كه عنصر آسيب به ديكران و انصاف تنها كَينهاى ممكن براى طبقهبندى تخلفها در كونهُ تخلف اخلاقى باشد (توجيه). كسانى هم دربارة معيارهاى جديت و استقلال از مرجع

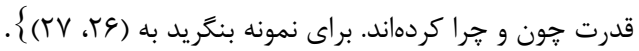
קنان كه پِيشتر آمد تحقيقهاى توريل و همكارانش نشان مىدهد

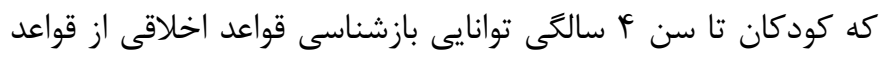

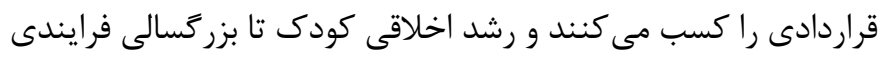
است يكسر در دامنه خود قواعد اخلاقى و مستقل از دامنهُ قراردادها.

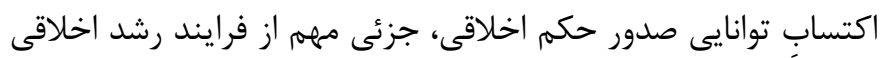
است و منظور از "رشد اخلاقى" نه تنها رفتارها و عواطف اجتماع يسند (Prosocial)

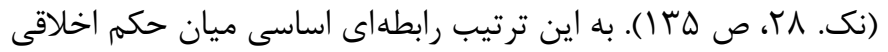

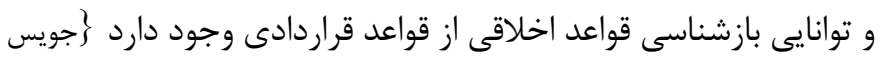
تا آنجا يِيش مىرود كه مى كويد: (اين نتايج به دست آمده از روانشناسى

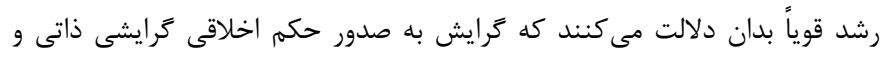

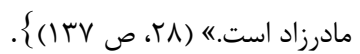

\section{بخش جهار ) يزوهش هاى بلر دربارهُ روانبيمارى}

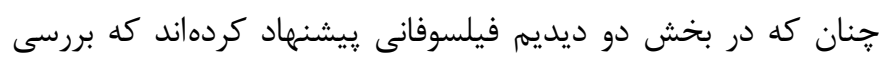

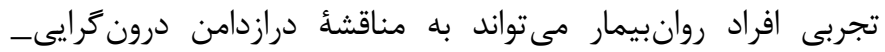
برون كرايى دربارة ربط باورهاى اخلاقى و انخيزش اخلاقى فيصله دهد. بلر (9)، و بلر و ديكران (•l) با كاربست (آزمون توريل) بر جامعهاى مشتمل بر بزهكاران روانبيمار و غيرروانبيمار (كروه كنترل) كوشيدند حساسيت بزهكاران روانبيمار به تمايز اخلاقى_قراردادى و توانايى ايشان

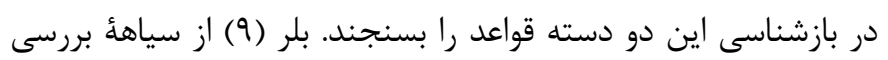

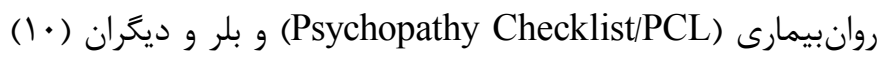

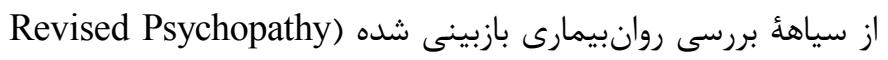

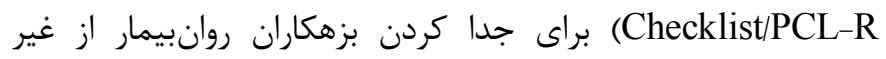
روانبيمار استفاده كردند. بلر در مقياس • F نمرهاي اين دو فهرست

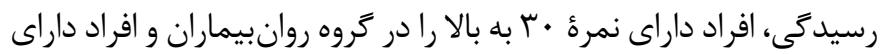

زيباشناختى و يا مصلحتانديشانه) متمايز كنده (سT، ص سT). نوجى

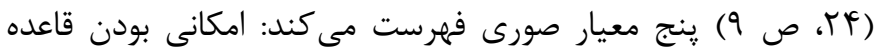
Rule contingency)، تغييريذيرى قاعده (Rule alterability)،

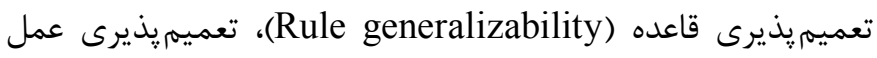
و شدت و حدت عمل (Act generalizability)

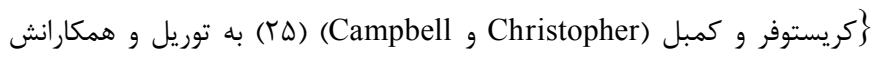
ايراد كرفتهاند كه معيارهاى ايشان معيارهاى صورى كانتى است. توريل و همكارانش يذيرفتهاند كه معيارها كانتىاند اما كفتهاند كه معيارهاى اخلاق هنجارى مثلا

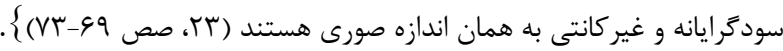
از سوى ديكر مقولئ توجيه به دلايلى اختصاص دارد كه افراد در توجيه

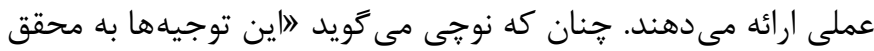

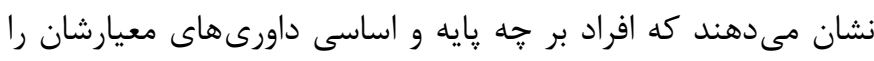

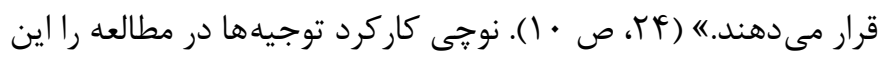

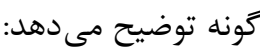
"اتوجيههايى كه افراد براى داورى هاى معيارشان بيان مى دارند نيز در

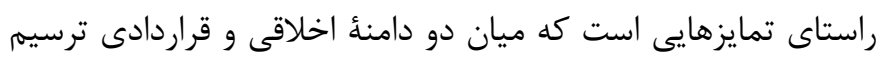
كرديم. احكام مربوط به امور اخلاقى را بر حسب آسيبرسان بودن يا دانيا نامنصفانه بودن عمل مورد بحث توجيه مى كنيم و احكام مربوط به

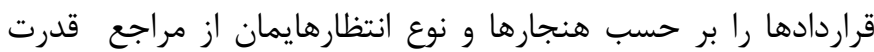
توجيه مى كنيم." (أT، ص • (l).

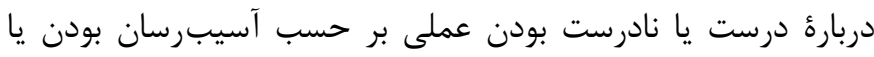

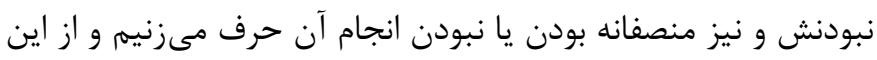

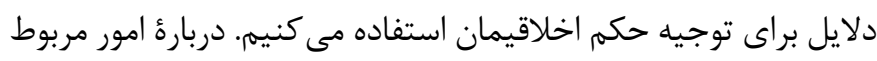

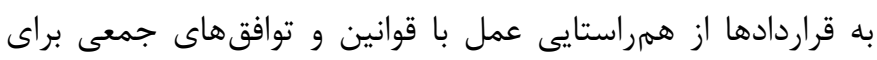

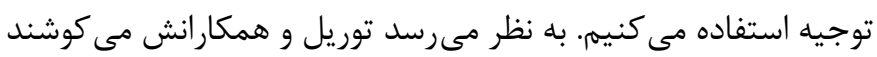

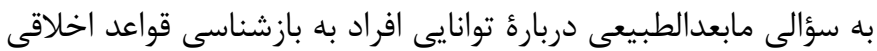

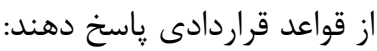
جه كسى قادر به بازشناسى و تمايز دادن قواعد اخلاقى از قوادند قواعد

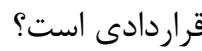
آزمون توريل تلاشى است براى ياسخ به اين سؤال. آزمون را اين كَونه

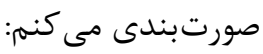

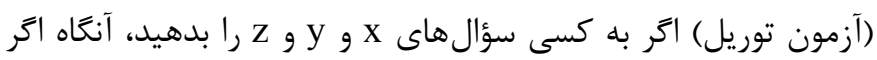

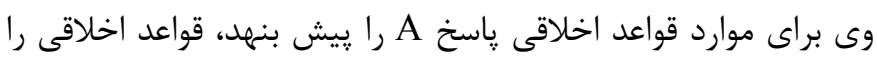

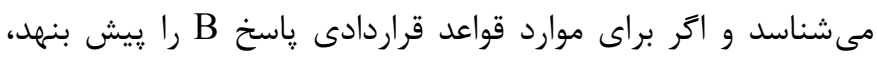
قواعد قراردادى را مىشناسد.

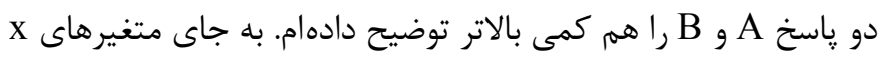
و y و در (آزمون توريل) هم مى توان سؤال هاى (جديت)، (توجيه) و 
اخلاقى جيست؟ و در نهايت (ت) پاسخ به اين سؤال كه جه رابطهاى ميان شناخت اخلاقى و مسئوليت اخلاقى و حقوقى وجود دارد؟ در اين بخش تنها به يرسش (ب) خواهم يرداخت \}توضيح مفصل اين جهار برسش

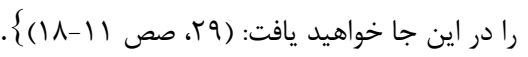

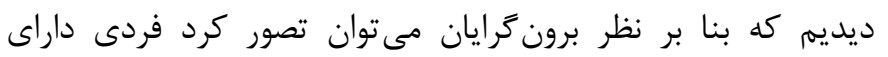

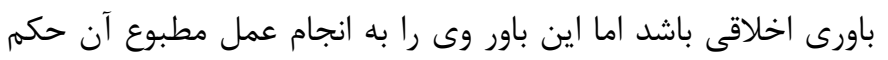

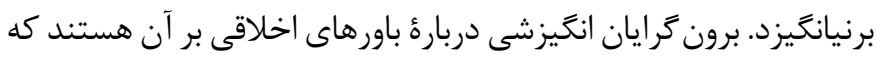
روان بيماران مصداقهاى واقعى و تحققهاى اين افراد ناخلاقى هستند.

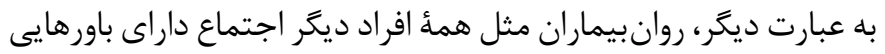

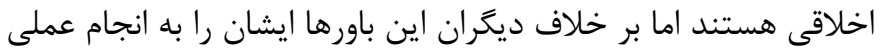

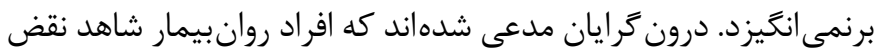

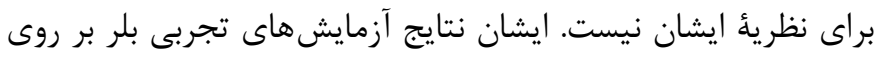

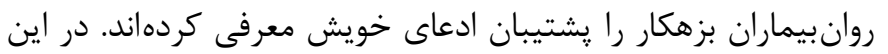
بخش نخست مى كوشم نشان دهم كه جَّونه درون كرايان از يافته هاى

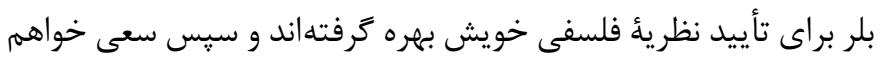

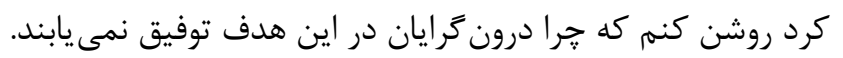

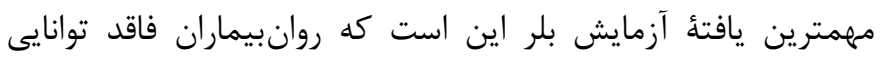
بازشناسى تخلفهاى اخلاقى از تخلفهاى قراردادى هستند:

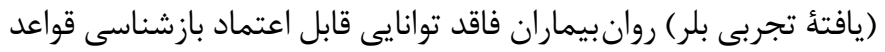
اخلاقى از قواعد قراردادى هستند. جنين يافتهايى حاصل دو جيز است: پيش فرضى كه بلر از توريل به

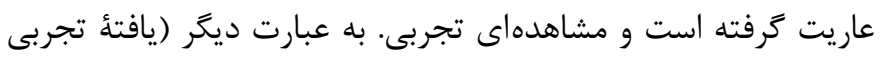
بلر ) نتيجة منطقى اين دو ادعا است:

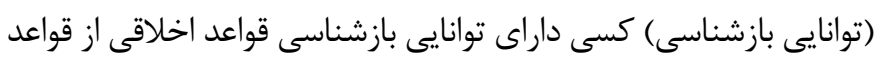

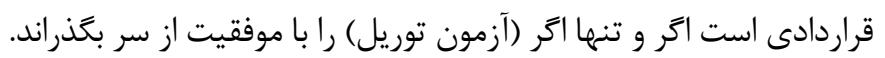
(مشاهدة تجربى بلر) روانبيماران در (آزمون توريل) ناموفق هستند.

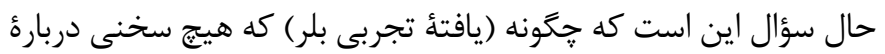

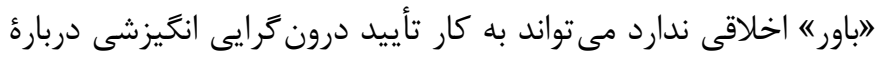
باورهاى اخلاقى بيايد؟ قول زير از لوى (Levy) براى فهم نتايج فلسفى مطالعهُ بلر و توضيح اين ارتباط بسيار ياريخر است:

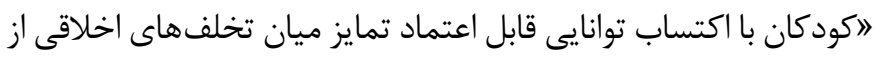
تخلف هاى قراردادى شناخت اخلاقى را كسب مى كنند. اكر ايشان فاقد

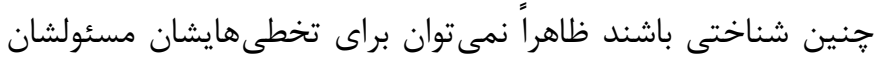

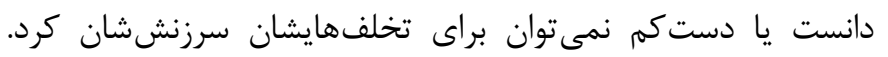
يزوهشهاى جديد بر آن دلالت مى كنند كه دستهاى از كسانى كه

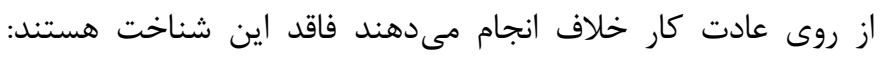
روانبيماران. [...] بلر متوجه شد كه روانبيماران (بر خلاف كودكان

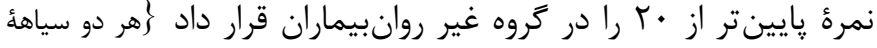
بررسى با مشكلاتى فلسفى و روش شناختى دست به كَيبان هستند. براى بحث در اين

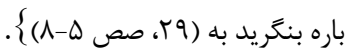

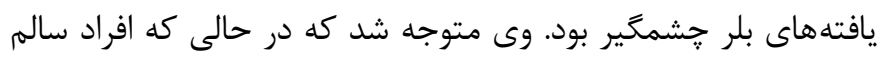

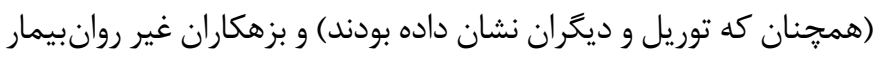

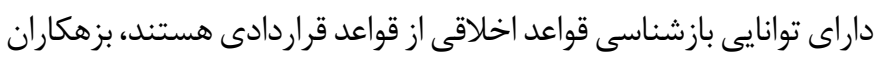

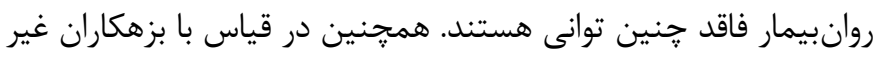
روانبيمار و افراد سالم، بزهكاران روانبيمار توجيههاى ديخرى براى ممنوعيت تخلفهاى اخلاقى به دست مىدهند. افراد كروه كنترل در آزمون بلر، يعنى بزهكاران سالم، درست مانند افراد سالم دلايل مجزايى براى توجيه مجاز نبودن تخلفهاى اخلاقى و تخلفهاى قراردادى

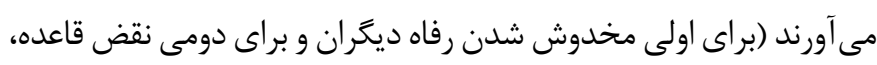

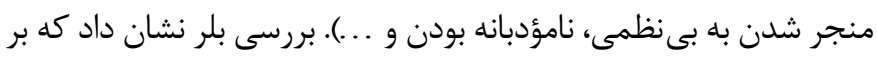

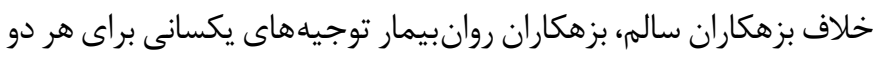

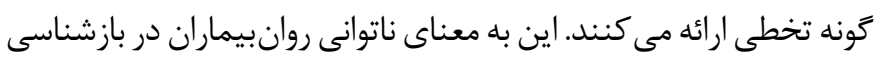

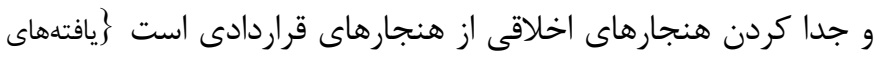
بلر بسيار بيش از آن جيزى است كه در اين بخش آوردام. به دليل محدوديت جا تنها به اين اكتفا مى كنم كه وى تبيينى براى اين ناتوانى ييش مىنهد و از آن مى كويد كه إنه علت توانايى بازشناسى تخلف هاى اخلاقى از قراردادى داشتن سازوكار بازدارى خشونت است. به زعم بلر اين سازوكار با ايجاد حس بيزارى (Aversion) باعث مىشود كه فرد به تخلفهاى اخلاقى در فعاليت تمايز اخلاقى /قراردادى واكنش نشان دهد. به نظر بلر حنين سازوكارى در افراد روان بيمار دهار

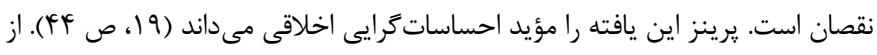

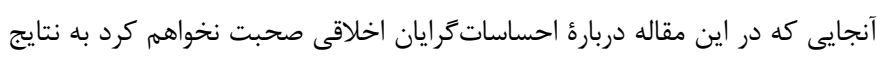
تحقيقات بلر براى اين رويكرد نيز نخواهم برداخت؛

\section{بخش ينج) استدلال سينوت-آرمسترانَ} تاكنون عمدتاً دربارٔ پايئ تجربى مطالعات توريل در مورد تمايز

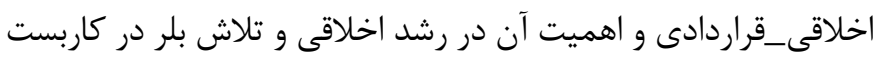

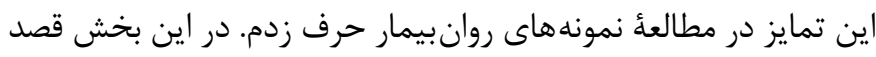

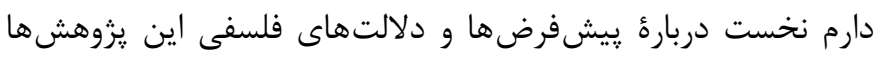

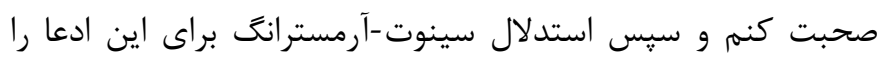

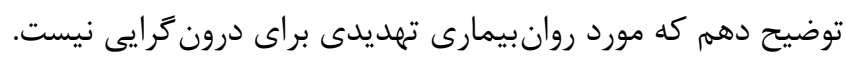

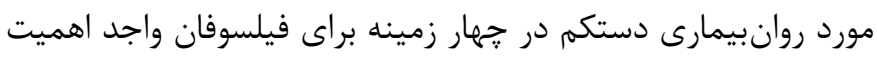
است: (الف) پاسخ به اين ترسش كه جه توجيهى براى اخلاقى بودن

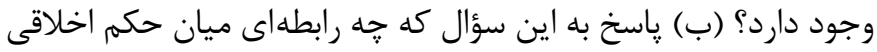
و انكيزش اخلاقى وجود دارد؟ (ب) يُاسخ به اين يرسش كه ماهيت حكم 
نبايد (نتيجه (ق*) را جنان خواند كه گويى روانبيماران فاقد باور اخلاقى هستند. (نتيجه ا**) مى كويد كه روانبيماران داراى باورهاى اخلاقى هستند اما باورهاى اخلاقىاى كه ايشان دارند فاقد "توجيه مناسب" هوتئ است. "توجيه مناسب" براى باور اخلاقى جيست؟ به نظر بلر توجيه

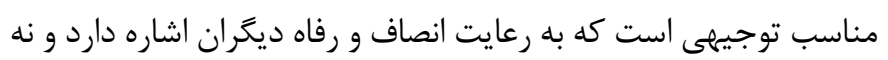

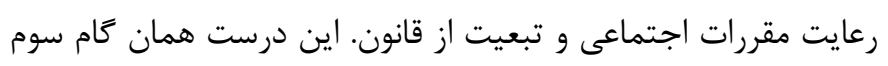

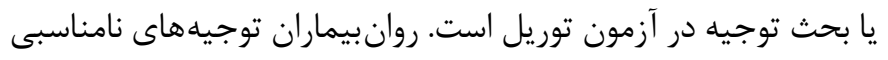

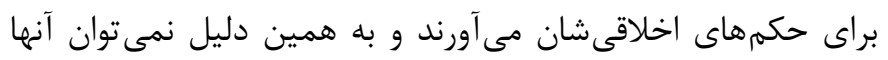
را داراى شناخت اخلاقى دانست. بحث توجيه لولايى است كه توانايى بازشناسى را به شناخت اخلاقى متصل مى كند. توانايى بازشناسى تخلفهاى اخلاقى و قراردادى و آزمون توريل را به ياد بياوريم: (توانايى بازشناسى) كسى داراى توانايى بازشناسى قواعد اخلاقى از

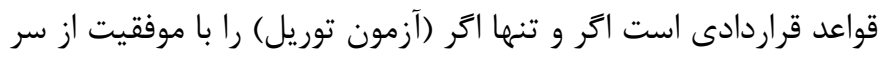

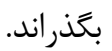

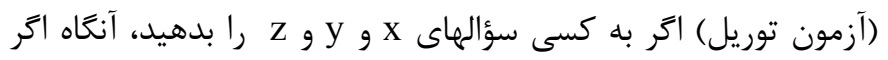

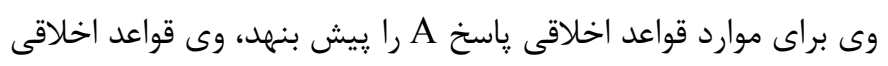

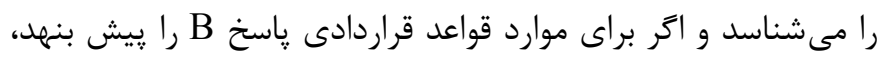
قواعد قراردادى را مىشناسد. ديديم كه توريل از دو مقولهٔ متفاوت "داورى معيار" و "توجيه" در

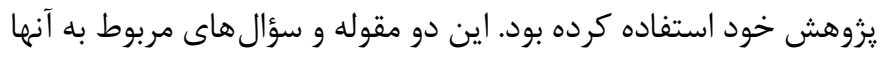

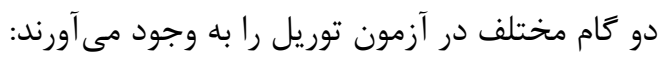
(آزمون معيار توريل) اگر به كسى سؤال هاى (جديت) و (مرجع قدرت)

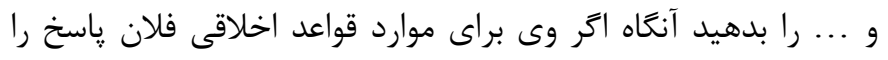

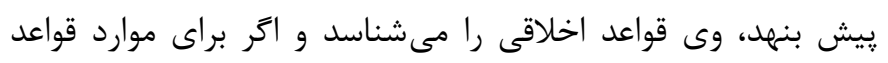

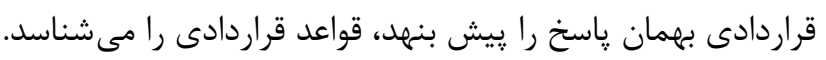

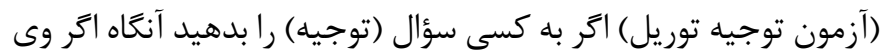
براى موارد قواعد اخلاقى فلان پاسخ را يِيش بنهل، وى قواعد اخلاقى را

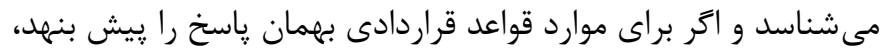
قواعد قراردادى را مى شناسد. اين دو آزمون در حقيقت گامهاى دوم و سوم در آزمون مادئن توريل هستند

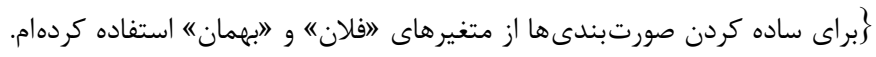

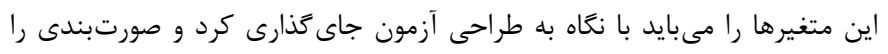

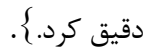
با متمايز كردن دو كام در آزمون توريل مى توان (توانايى بازشناسى) را

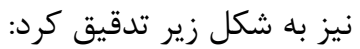

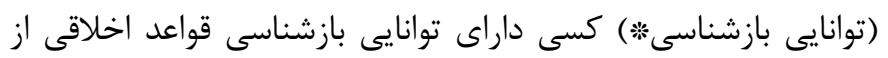

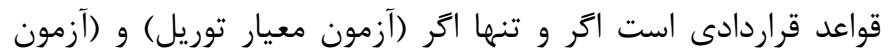

و گروه كنترل افراد بزهكار) نمىتوانند به شيوهاى قابل اعتماد ميان تخلفهاى اخلاقى و تخلفهاى قراردادى فرق قايل شوند (9، · (). اين

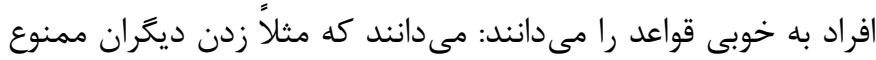

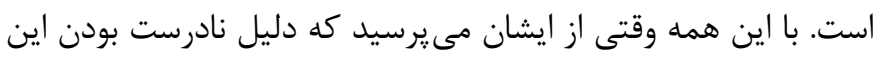

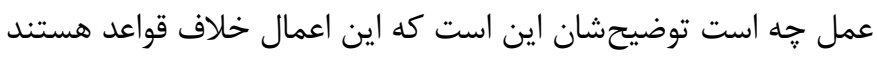

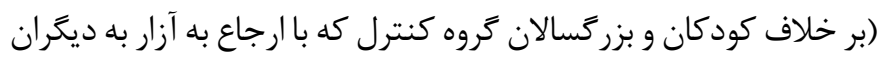

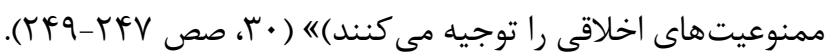
لوى به خوبى از ارتباط توانايى تشخيص تخلفهاى اخلاقى از تخلفهاى قراردادى با شناخت اخلاقى و مسئوليت (اخلاقى يا حقوقى) و در نتيجه اهميت نمونهٔ روانبيمارى براى اين بحث هاى فلسفى سخن مى كويد. به نظر وى روان بيماران فاقد مسئوليت اخلاقى هستند، به اين دليل كه فاقد شناخت اخلاقى هستند و دليل فقدان شناخت اخلاقى در

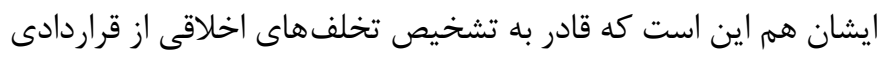

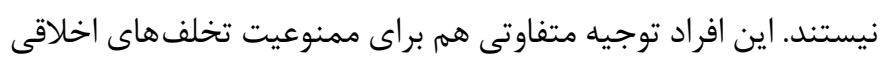

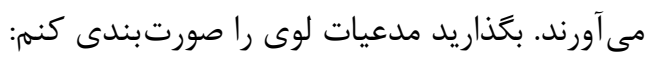
(لوى () فردى مانند ف داراى مسئوليت اخلاقى است تنها اكر داراى

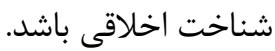
(لوى ؟) فردى مانند ف داراى شناخت اخلاقى است تنها اتر داراى توانايى قابل اعتماد بازشناسى قواعد اخلاقى از قواعد قراردادى باشد.

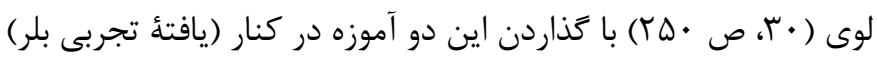
نتيجه مى كيرد كه: (نتيجه () روانبيماران فاقد شناخت اخلاقى هستند. (نتيجه Y) روانبيماران فاقد مسئوليت اخلاقى هستند.

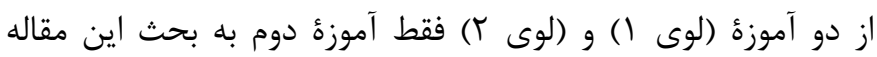

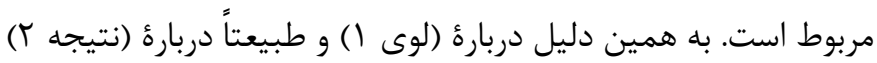
بحث نخواهم كرد. درون كرايان و برون كرايان دربارة باورهاى اخلاقى،

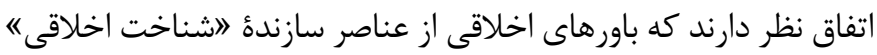

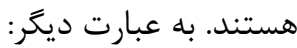
شناخت اخلاقى مجموعهاى است از باورهاى اخلاقىاى كه صادق و موجه هستند.

با كمك اين توضيح مى توان (لوى r) را اين كونه بازنويسى كرد:

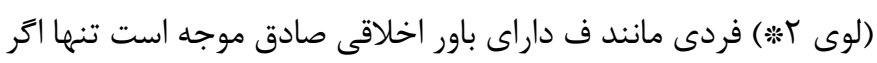

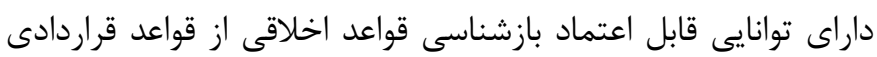
باشد. با در نظر كرفتن (يافتهٔ تجربى بلر) در كنار (لوى Гاث*) نيز مىتوان

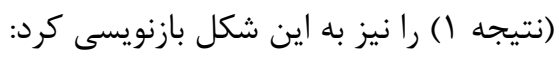
(نتيجه |**) روان بيماران فاقد باور اخلاقى صادق موجه هستند. 
كه روانبيمارى شاهد نقضى براى درونَرايى نيست. ادعاى (لوى ץ־*)

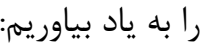
(لوى זّ*) فردى مانند (ف) داراى باور اخلاقى صادق موجه است

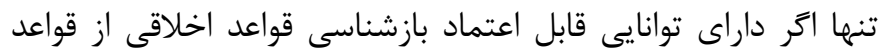

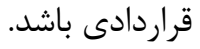
ييدا است كه (فرض درون گرايانه) ادعايى ضعيفتر از (لوى ץ"**) است و توانايى قابل اعتماد بازشناسى قواعد اخلاقى از قواعد قراردادى را تنها براى داشتن باورى اخلاقى و نه شناخت اخلاقى ضرورى مى شمارد. در قولى كه نقلش آمد سينوت-آرمسترانگ در توجيه (فرض درون كرايانه)، كه مقدمٔ مههم و كليدى استدلال وى است، برهانى از راه قياس ييش نهاده است. وى اخلاق را همانند زيباشناسى مى داند و بيان مى دارد كه همان گونه كه در زيباشناسى به توانايى تشخيص ارزش زيباشناختى از ارزش تجارى نياز است در اخلاق هم به توانايى تمايز اصول اخلاقى از

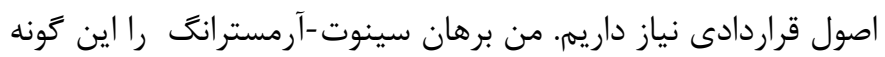

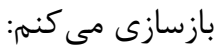
(مقدمة () فردى مانند (ف) مى تواند باورى زيباشناختى داشته باشد تنها اگر داراى توانايى قابل اعتماد بازشناسى ارزشهاى زيباشناختى از ارزش هاى تجارى باشد.

(مقدمٔ r) قواعد اخلاقى همانند ارزشهاى زيباشناختى هستند. (مقدمة ץ) قواعد قراردادى همانند ارزشهاى تجارى هستند. (مقدمة f) باور هاى اخلاقى همانند باورهاى زيباشناختى هستند. (مقدمة Q) باورهاى قراردادى همانند باورهاى تجارى هستند.

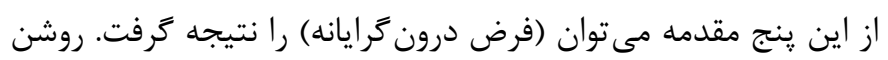

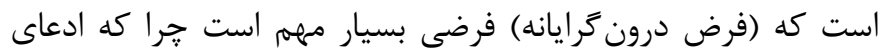
سينوت-آرمسترانگ به آن وابسته است. حال اكر توجيه مناسبى براى

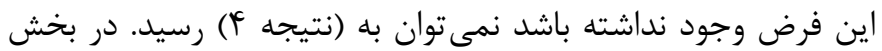
بعد به بررسى برهان از راه قياس سينوت-آرمسترانگ براى توجيه اين فرض خواهم برداخت.

\section{بخش شش) نقد استدلال سينوت-آرمسترانت تا به حال از دو ادعاى درون}

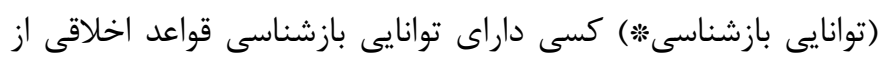

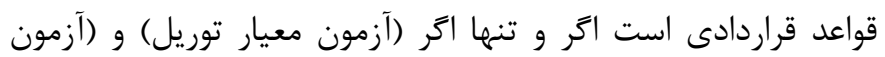
توجيه توريل) را با موفقيت از سر بخذراند. (فرض درون كرايانه) فردى مانند (ف) مى تواند باورى اخلاقى داشته باشد تنها اگر داراى توانايى قابل اعتماد بازشناسى قواعد اخلاقى از
توجيه توريل) را با موفقيت از سر بكذراند. بلر با مفروض ترفتن (توانايى بازشناسى*) نشان مى دهد كه روانبيماران

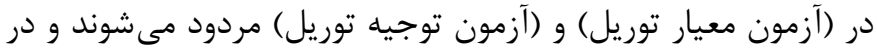

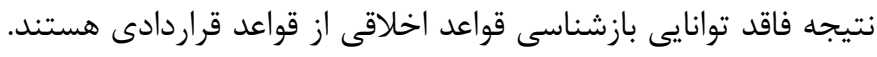

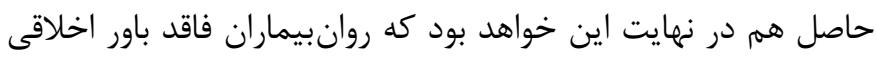
صادق موجه هستند (نتيجه ا**). جنان كه ديديم تحقيقات بلر با هان "اتوجيه" سر و كار دارند و نشان مى دهند كه روان بيماران نمىتوانند توجيه مناسبى براى باورهاى خود بياورند. جنان كه آمد مسئلة مورد بحث در مناقشأ درونَرايى_برون كرايى بسيار ريشهاىتر و اين است

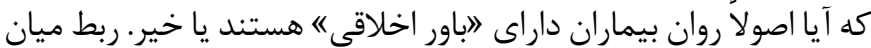
بحث روانبيمارى و درون كرايى را سينوت-آرمسترانت به خوبى بيان

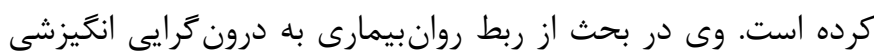
يشيشفرض مهمى ميان درون كرايان را روشن مى كند:

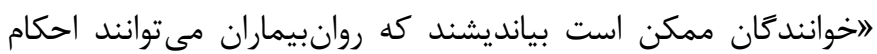

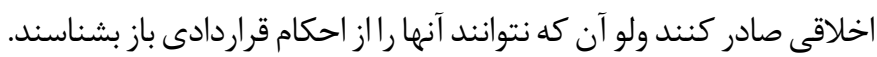
با اين حال اكر دلال هنرياى نتواند ارزش زيباشناختى را از ارزش تجارى باز بشناسد نمىتواند حكم زيباشناختى واقعىاى صادر كند. بر همين قياس مىتوان ادعا كرد كه اخر روانبيماران نتوانند احكام اخلاقى را از احكام قراردادى باز بشناسند آنغاه نمى توانند حكم اخلاقى واقعى إى صادر

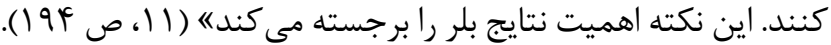
ييش از توضيح سخنان سينوت-آرمسترانگ بايد درباره مسئلهاى

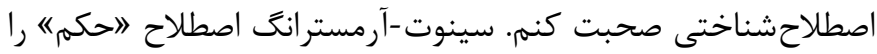

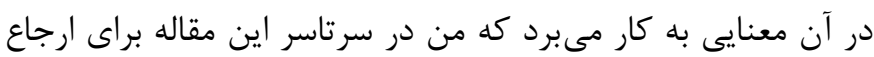

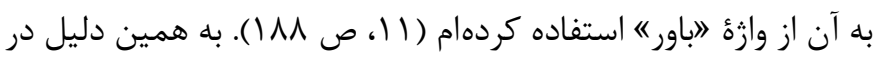
صورتبندى مدعيات وى به جاى "حكمه لفظ "اباور" را به كار مىبرم. نخستين ادعاى سينوت-آرمسترانگ كه مههمترين فرض درون كرايان

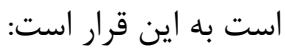
(فرض درون گرايانه) فردى مانند ف مى تواند باورى اخلاقى داشته باشد تنها اكر داراى توانايى قابل اعتماد بازشناسى قواعد اخلاقى از قواعد فردائ

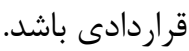
سينوت-آرمسترانَ و ديخر درون كرايان از كذاردن ادعاى فوق در كنار (يافته تجربى بلر) نتيجه هاى زير را اخذ مى كنند: (نتيجه ؟َ) روان بيماران نمى توانند باورى اخلاقى داشته باشند. (نتيجه f) مورد روانبيمارى شاهدى عليه درون كرايى نيست. سينوت-آرمسترانگ مى گويد كه روان بيمارى شاهدى براى برون خرايى و خطرى براى درون گرايى نيست. (فرض درون گرايانه) يلى است كه (يافتهُ تجربى بلر) را به اين ادعاى طرفداران درون ترايى وصل مى كند 
تجارى نيست بهتر است از شباهت روانبيمار به هنرمندى حرف بزنيم

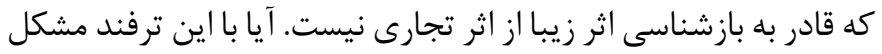

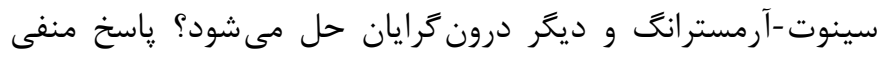

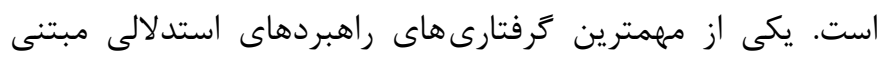

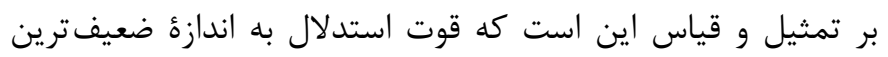

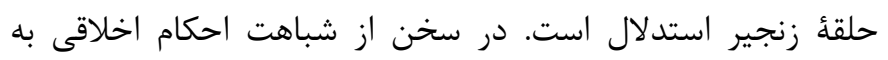

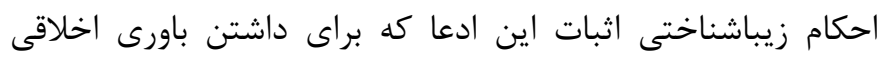

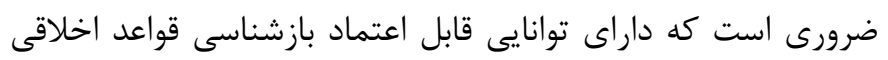
از قواعد قراردادى باشيم (فرض درون كرايانه)، خود منوط مى شود به اثبات ادعايى ديكر: براى داشتن باورى زيباشناختى ضرورت دارد

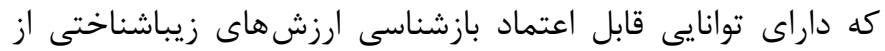
ارزشهاى تجارى باشيم، يعنى (مقدمة (). حال تنها كارى كه انجام

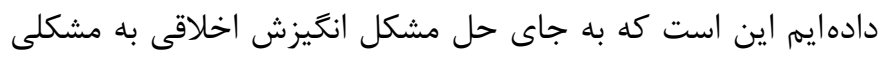

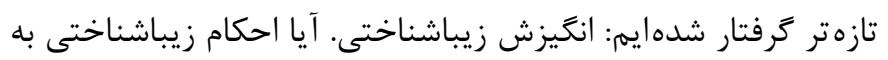

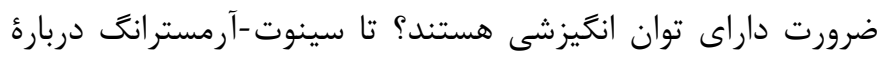

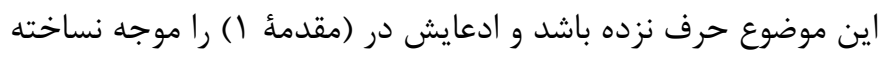
باشد نمى توان درباره توجيه ادعاى (فرض درون كرايانه) سخن تفت.

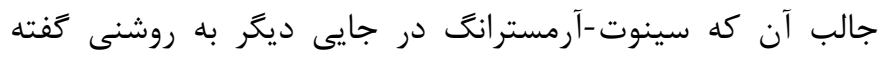
است كه احكام (باورهاى) اخلاقى از نظر انكَيزشى با احكام (باورهاى) زيباشناختى فرق دارند و شباهتى ميان آنها برقرار نيست:

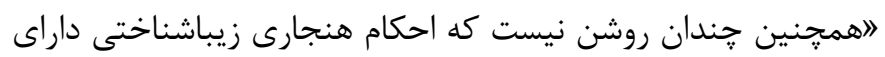
انكَيزش خاصى باشند (يا هماند احكام اخلاقى مدعى عينيت باشنداند).

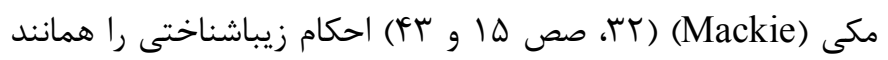

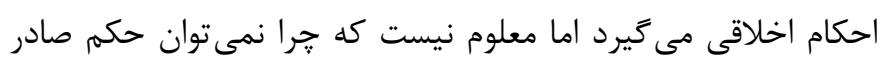

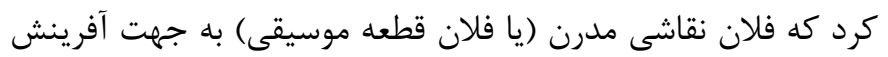

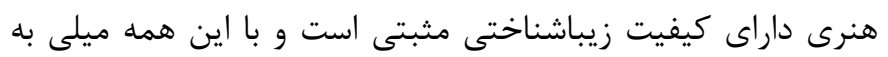

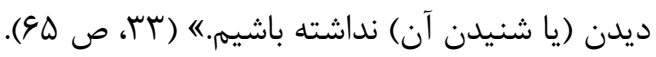

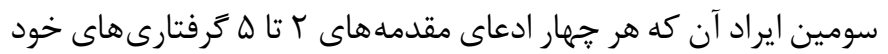
را دارند. روشن نيست جرا اين همانندى ها برقرار هستند و خكونه و بر آران

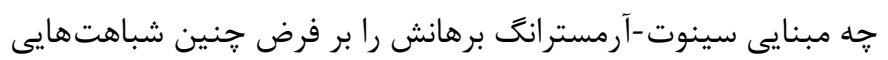
استوار كرده است. براى اثبات (فرض درونكرايانه) نياز است بسيار

بيشتر از آنجه كه كَفته شده است بيان شود.

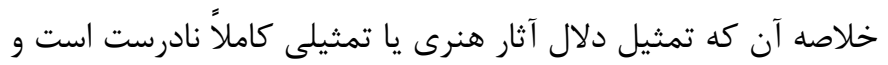

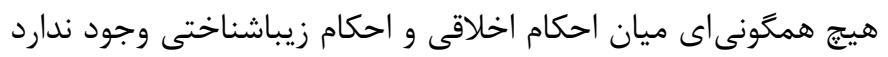

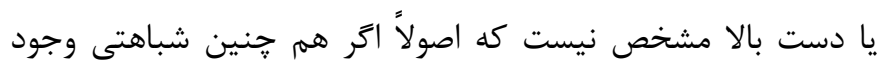

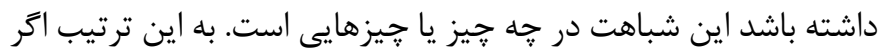

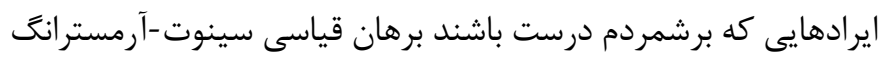

همجنين ديديم كه بنا بر نتايج آزمايشهاى بلر روانبيماران در (آزمون معيار توريل) و (آزمون توجيه توريل) مردود مىشوند و به همين دليل قادر به بازشناسى قواعد اخلاقى از قواعد قراردادى نيستند. در نتيجه

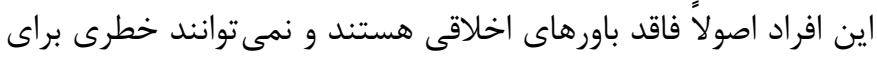

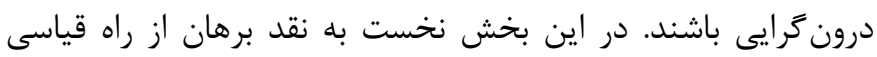

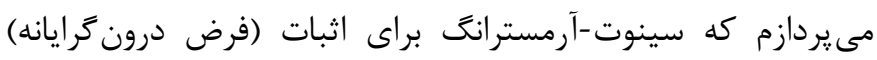
آورده است. קنان كه خواهيم ديد اين برهان در نيل به هدفش ناكام است. در بخش دوم استدلال خواهم كرد كه (فرض درون كرايانه) از از

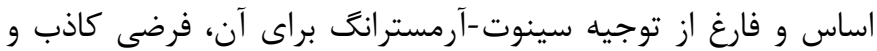
نادرست است.

نقد اول برهان از راه قياس سينوت-آرمسترانگ از جهات بسيارى ناموفق است.

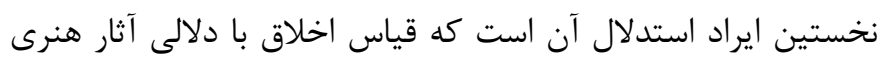

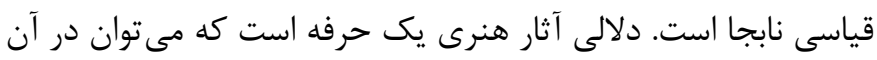

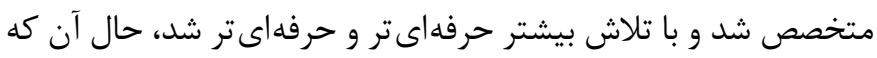
اخلاقى بودن به هر جيزى هم ماننده باشد هيج شباهتى به يك حرفه ندارد. بر خلاف دلال بودن كه يك حرفه و شغل است اخلاقى بودن

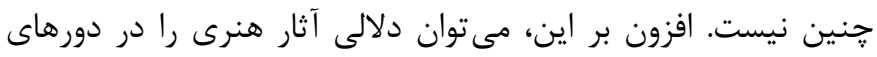

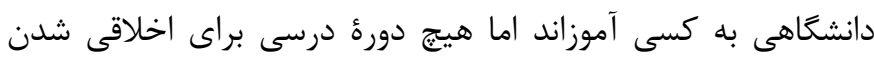

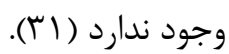
دومين مشكل اين است كه مى توان براى باورهاى اخلاقى از انگَيزش

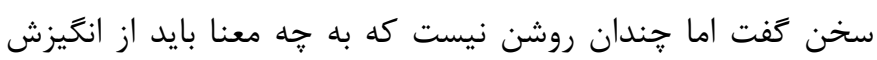

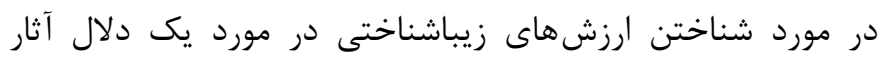

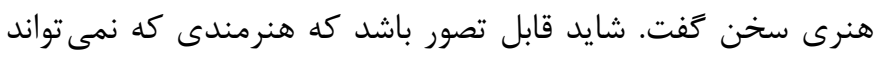
ارزشهاى زيباشناختى را از ارزشهاى تجارى تشخيص دهد نخواهد توانست اثرى هنرى خلق كند اما معلوم نيست جخَّنه مى توان رابطهاى مشابه ميان تشخيص ارزش هنرى از ارزش تجارى از يك آن

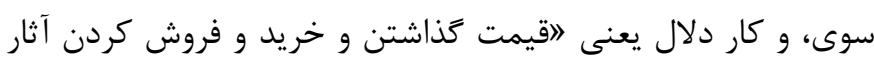
هنرى"، از سوى ديخر، برقرار كرد. به سخنى ديخر شايد بتوان ميان دئن

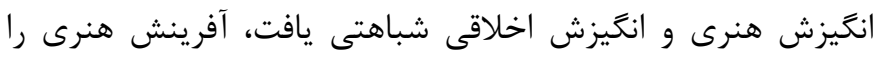

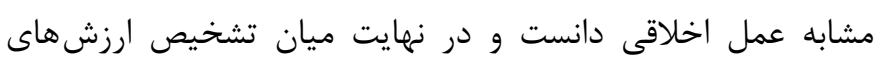
هنرى از تجارى و تشخيص قواعد اخلاقى از قراردادى همانندى يافت. با اين حال اين همانندى فرق بسيارى با شباهت عمل اخلاقى و عمل

$$
\text { خريد و فروش آثار هنرى دارد. }
$$

شايد راهى براى خلاصى از مشكل فوق اين باشد: به جاى تشبيه

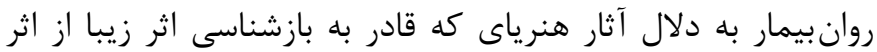


كنيم. شايد تنها فيلسوفان اخلاق به خاطر مسلح بودن به نظريههاى اخلاقى بتوانند توجيه هايى مناسب براى باورهاى اخلاقىشان بياورند. با اين حال نمى توان نتيجه گرفت كه آدميان عادى نآشنا به نظريههاى اخلاقى فاقد باورهايى اخلاقى هستند. افراد عادى شايد براى باورهايشان

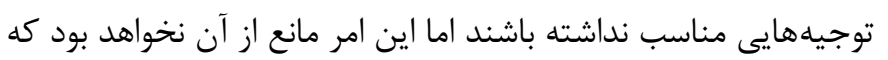
داراى باورهايى اخلاقى باشند. فقدان توجيه مناسب جايى ديخر دردسر ساز خواهد بود. اخر دغدغهمان شناخت اخلاقى آدميان باشد و نه صرفاً باورهاى اخلاقى ايشان، آنغاه سؤال از اين كه فرد توجيهى مناسب براى باور اخلاقى صادقش داشته است يا خير بسيار مهم خواهد بود. تنها در اين حالت است كه گذراندن يا مردود شدن در (آزمون معيار توريل) و (آزمون توجيه توريل) اهميت خواهد داشت و تعيين كننده خواهد بود. در آن وضعيت فرد عامىاى كه داراى اين باور اخلاقى است كه قتل بد است فاقد شناخت اخلاقى به اين كه قتل بد است خواهد بود. به اين دليل ساده كه توجيهى مناسب براى باور صادقش ندارد. به عبارت ديخر

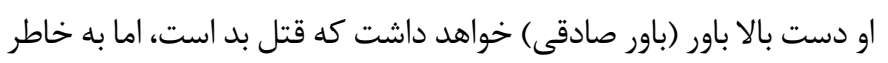
نداشتن توجيهى مناسب نخواهد دانست كه قتل بد است.

\section{نتيجه كيرى}

در اين مقاله يس از توضيح دو رويكرد دورنگرايانه و برونگرايانه به انخيزاننده بودن باورهاى اخلاقى با نگاه به يروهشهاى تجربى

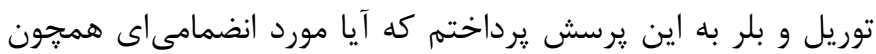

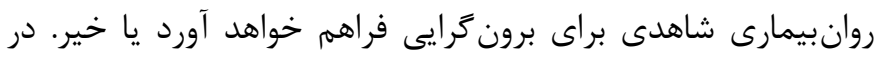

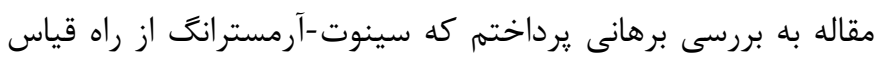
اخلاق به هنر فراهم كرده است تا نشان دهد كه يافتههاى تجربى بلر در مورد بزهكاران روانبيمار شاهدى عليه درون گرايى انگَزشى نيست. در نهايت استدلال كردم كه (الف) برهان متكى بر قياس سينوت آرمسترانت گرفتار مشكلات متعددى است و نمىتواند به هدفى كه مى جويد نايل شود، (ب) درون گرايى انخيزشى بر پيشفرضى نادرست تكيه دارد.

\section{تشكر و فندردانى}

اين مقاله با حمايت ستاد توسعه علوم و فناورى هاى شناختى معاونت

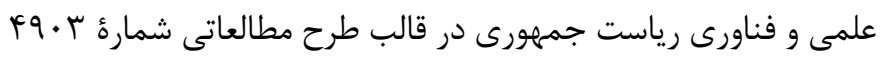

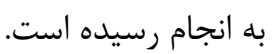

براى (فرض درون گرايانه) برهانى ناكار آمد خواهد بود.

نقد دوم

تا اين جا از آن كَفتم كه برهان از راه قياس سينوت-آرمسترانگ براى

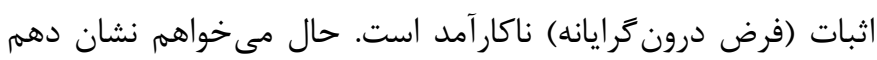

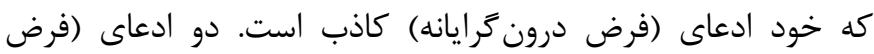

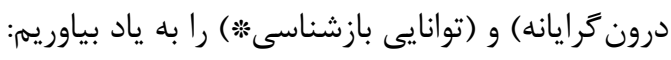

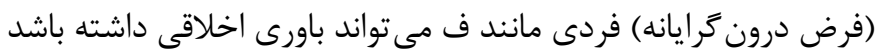
تنها اگر داراى توانايى قابل اعتماد بازشناسى قواعد اخلاقى از قواعد

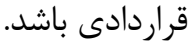
(توانايى بازشناسى*) كسى داراى توانيى بازشناسى قواعد اخلاقى از قواعد قراردادى است اكر و تنها اتر (آزمون معيار توريل) و (آزمون توجيه توريل) را با موفقيت از سر بكذراند.

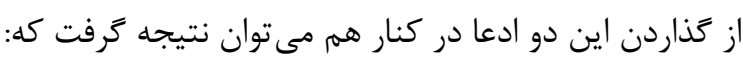

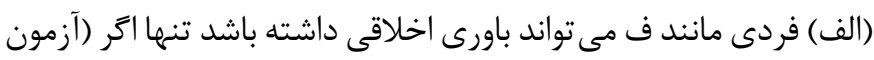

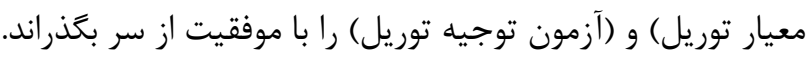

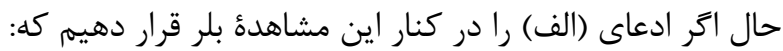

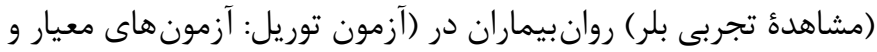
توجيه) ناموفق هستند.

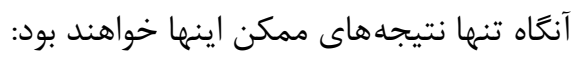

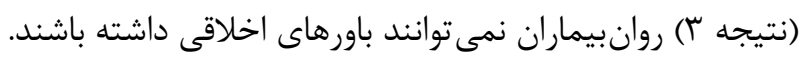
(نتيجه \&) مورد روان بيمارى شاهدى عليه درون خرايى نيست.

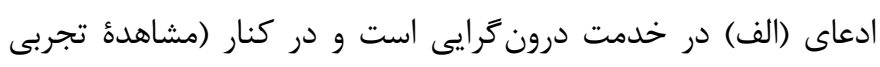

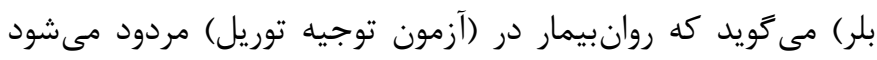

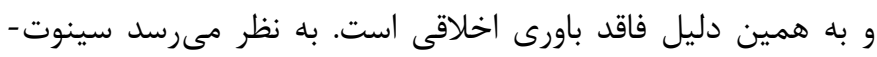
آرمسترانگ و ديگر درون كرايان به مشكلى اساسى گرفتارند: ادعاى (الف) از آن مى گويد كه فردى مثل (ف) نمى تواند داراى باور اخلاقى همجيحون

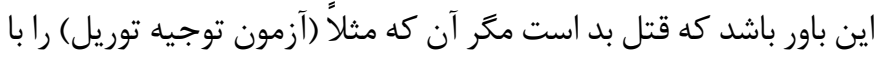
موفقيت كذرانده باشد و توجيهش براى بد بودن قتل اين باشد كه اين كار

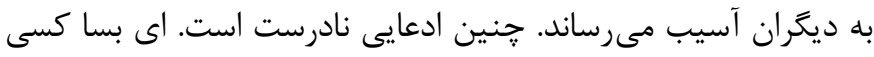

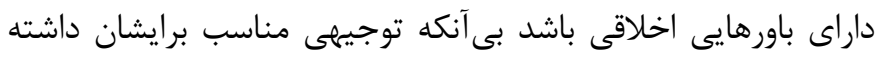

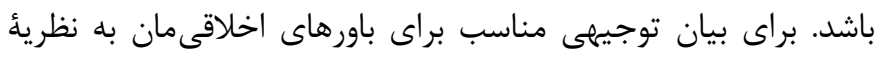

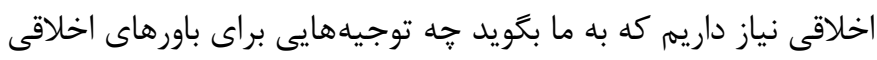
مناسب هستند و باورمان به اين كه قتل بد است را جحكونه بايد توجيه 


\section{References}

1. Smith M. The moral problem. Oxford:Blackwell Publishing; 1994.

2. Brink DO. Moral realism and the foundations of ethics. Cambridge:Cambridge University Press;1989.

3. Piaget J. The moral judgment of the child. New York:Free Press; 1932.

4. Kohlberg L. The philosophy of moral development: The nature and validity of moral stages. Essays on moral development: Vol. 1. San Francisco:Harper \& Row Publishers;1981.

5. Kohlberg L. The philosophy of moral development: the nature and validity of moral stages. Essays on moral development: Vol. 2. San Francisco:Harper \& Row Publishers;1984. 6. Turiel E. The development of social knowledge: Morality and convention. Cambridge:Cambridge University Press;1983. 7. Turiel E. The culture of morality: Social development, context, and conflict. Cambridge:Cambridge University Press;2002. 8. Turiel E, Nucci LP. Social interactions and the development of social concepts in preschool children. Child Development. 1978;(49):400-407.

9. Blair RJR. A cognitive developmental approach to morality: Investigating the psychopath. Cognition. 1995;57(1):1-29.

10. Blair RJR, Jones L, Clark F. Smith M. Is the psychopath "morally insane"?. Personality and Individual Differences. 1995;19(5):741-752.

11. Sinnott-Armstrong W. Do Psychopaths refute internalism?. In: Schramme T, editor. Being amoral: Psychopathy and moral incapacity. Cambridge:The MIT Press;2014. pp. 187-208.

12. Björnsson G, Strandberg C, Francén Olinder R, Eriksson J, Björklund F. Motivational internalism. Oxford:Oxford University Press;2015.

13. Hills A. Cognitivism about moral judgement. In: Shafer-Landau R, editor. Oxford studies in metaethics. Oxford:Oxford University Press;2015. pp. 1-25.

14. Kauppinen A. Moral sentimentalism [Internet] 2014 [updated 2010 Jan 29; cited 30 April 2018]. Available from: https:// plato.stanford.edu/entries/moral-sentimentalism/
15. Gendler TS, Hawthorne J. Conceivability and Possibility. 1st ed. Oxford:Clarendon Press;2002.

16. Prinz J. An empirical case for motivational internalism. In: Björnsson G, Strandberg C, Francén Olinder R, Eriksson J, Björklund F, editors. Motivational internalism. Oxford:Oxford University Press;2015. pp. 61-84.

17. Kumar V. Psychopathy and internalism. Canadian Journal of Philosophy. 2016;46(3):318-345.

18. Nichols S. Sentimental rules: On the natural foundations of moral judgment. Oxford:Oxford University Press;2004.

19. Prinz J. The emotional construction of morals. Oxford:Oxford University Press;2007.

20. Nucci L, Powers DB. Social cognitive domain theory and moral education. In: Nucci L, Navaez D, Krettenauer T, editors. Handbook of moral and character education. 2nd ed. New York and London:Routledge;2014. pp. 121-139.

21. Snarey J, Samuelson PL. Lawrence Kohlberg's revolutionary ideas: Moral education in the cognitive-developmental tradition. In: Nucci L, Navaez D, Krettenauer T, editors. Handbook of moral and character education. 2nd ed. New York and London:Routledge;2014. pp. 61-83.

22. Prinz J. Sentimentalism and the moral brain. In: Liao SM, editor. Moral brain: The neuroscience of morality. Oxford:Oxford University Press;2016. pp. 45-73.

23. Helwig C, Turiel E, Nuuci LP. The virtues and vices of moral development theorists. Developmental Review. 1996;(16):69-107.

24. Nucci L. Education in the moral domain. Cambridge:Cambridge University Press;2001.

25. Campbell RL, Christopher JC. Moral development theory: A critique of its Kantian presuppositions. Developmental Review. 1996;16(1):1-47.

26. Maibom HL. Moral unreason: The case of psychopathy. Mind \& Language. 2005;20(2):237-257.

27. Shoemaker DW. Psychopathy, responsibility, and the moral/conventional distinction. The Southern Journal of Philoso- 
phy. 2011;49(1):99-124.

28. Joyce R. The evolution of morality. Cambridge:The MIT Press;2006.

29. Schramme T. Introduction. In: Schramme T, editor. Being amoral: Psychopathy and moral incapacity. Cambridge: The MIT Press;2014. pp. 1-40.

30. Levy N. Neuroethics: Challenges for the 21th century. Cambridge:Cambridge University Press;2007.
31. Ryle G. Can Virtue Be Taught?. In: Dearden RE, Hirst P, Peters RS, editors. Education and the development of reason. London:Routledge;1972. pp. 323-332.

32. Mackie J. Ethics: Inventing right and wrong. New York:Penguin;1990.

33. Sinnott-Armstrong W. Mackie's internalisms. In: Joyce R, Kirchin S, editors. A world without values. Dordrecht:Springer;2010. pp. 55-70. 